REVIEW

\title{
Effects of pH on coastal marine phytoplankton
}

\author{
Kenneth R. Hinga* \\ Graduate School of Oceanography, University of Rhode Island, South Ferry Road, Narragansett, Rhode Island 02882, USA
}

\begin{abstract}
Twenty-one studies on the effects of $\mathrm{pH}$ on marine phytoplankton were found and are herein reviewed. Under laboratory conditions, the optimum pH for growth is between pH 6.3 and 10 . Some species can grow well at a wide range of $\mathrm{pH}$, while others have growth rates that vary greatly over a 0.5 to $1 \mathrm{pH}$ unit change. Different clones of the same species were found to have slightly to strikingly different relationships between $\mathrm{pH}$ and growth rate. The $\mathrm{pH}$ in typical coastal environments may vary by 1 or more pH units, with over $10 \%$ of observations being more than 0.5 units above or below equilibrium $\mathrm{pH}$. This range is great enough, relative to the observed $\mathrm{pH}$ effect on growth rate for many species, for seawater $\mathrm{pH}$ to affect the growth rate, and hence the timing and abundance of coastal marine phytoplankton species. Effects of $\mathrm{pH}$ are not limited to extreme $\mathrm{pH}$ conditions. The growth rates of some species are influenced significantly by changes in $\mathrm{pH}$ near the equilibrium $\mathrm{pH}$ of coastal seawater. Care must be taken in growth experiments with phytoplankton to avoid effects due to $\mathrm{pH}$ of the culture media. Eutrophication of coastal waters may amplify the range of $\mathrm{pH}$ found in coastal environments.
\end{abstract}

KEY WORDS: pH $\cdot$ Phytoplankton $\cdot$ Eutrophication

Resale or republication not permitted without written consent of the publisher

\section{INTRODUCTION}

The $\mathrm{pH}$ of seawater in the open ocean falls within a fairly narrow range, typically $0.3 \mathrm{pH}$ units (Skirrow 1975). In contrast, the $\mathrm{pH}$ of coastal waters varies by a much greater range. However, little attention has been paid to the effects of $\mathrm{pH}$ on the growth rate and ecology of marine phytoplankton, including those in coastal waters, perhaps because of an open-ocean view of 'a constant $\mathrm{pH}$ of seawater'. Authoritative volumes that review the ecology of marine phytoplankton usually do not consider $\mathrm{pH}$ as one of the possible factors that influences the growth rate or ecology of marine phytoplankton species. It is rare even to find $\mathrm{pH}$ listed as an index entry in such works.

This is in sharp contrast to the literature on freshwater phytoplankton. The sensitivity of lake phyto-

*E-mail: khinga@gso.uri.edu plankton to $\mathrm{pH}$ is of great interest, especially as a result of anthropogenic acidification of lakes. Studies have shown that the species composition of phytoplankton communities in lakes is highly correlated with lake pH (e.g. ter Braak \& van Dam 1989, Dixit et al. 1992). It appears possible to discern $\mathrm{pH}$ differences in lakes as small as $0.1 \mathrm{pH}$ unit by observing the phytoplankton community structure.

The objective of this paper is to review the $\mathrm{pH}$ range in coastal marine environments and assess its influence on the growth rate and ecology of marine phytoplankton. Examples of $\mathrm{pH}$ variability in coastal waters are given. Processes leading to $\mathrm{pH}$ variability are discussed briefly. The modest volume of literature that has addressed the effects of $\mathrm{pH}$ on marine phytoplankton is then reviewed. The information is primarily on growth rate, substrate uptake rate or final population size studies on individual species in culture. Some information is also available on mixed populations in marine enclosures and field populations. 


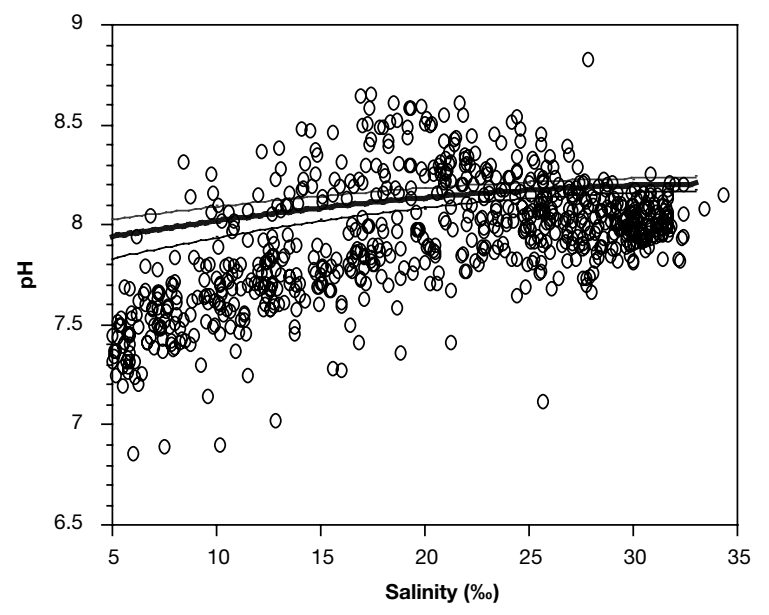

Fig. 1. Observed $\mathrm{pH}$ values (o) from a series of surveys in Delaware Bay (Sharp et al. 1980, Culberson et al. 1982, 1987a,b,c, 1988, Lebo et al. 1990). The equilibrium $\mathrm{pH}$ values (bold solid line) were calculated from the alkalinity-salinity relationship for the bay at $15^{\circ} \mathrm{C}$. The envelope around the equilibrium $\mathrm{pH}$ represents the uncertainty in the equilibrium $\mathrm{pH}$ resulting from the variability in the alkalinity-salinity relationship and the temperature range for Delaware Bay

\section{The origin of variability in coastal seawater $\mathrm{pH}$}

The $\mathrm{pH}$ of seawater responds to changes in: (1) the concentration of total dissolved $\mathrm{CO}_{2 i}$ (2) alkalinity; (3) temperature; and for deep waters, (4) pressure (Skirrow 1975). In each case, the magnitude of change varies with salinity because the concentration of salt influences the various equilibrium constants and because several components of sea salt are involved in the acid-base reactions of seawater.

The equilibrium $\mathrm{pH}$ of surface seawater, for a given temperature and salinity, is the $\mathrm{pH}$ of seawater in equilibrium with $\mathrm{CO}_{2}$ in the atmosphere. At equilibrium $\mathrm{pH}$, the partial pressure of $\mathrm{CO}_{2}$ in the seawater is the same as that in the atmosphere. In estuarine settings, there is usually a gradient in alkalinity between freshwater alkalinity and seawater alkalinity such that there is a resultant gradient in the equilibrium $\mathrm{pH}$. An example of an estuarine gradient in equilibrium $\mathrm{pH}$ is shown in Fig. 1 for Delaware Bay. The upper and lower curves indicate the upper and lower boundary of the $\mathrm{pH}$ range resulting from variability in the temperature and the variability in the observed alkalinity-salinity relationship for these observations. The alkalinity of rivers averages about $1000 \mu$ ueq $^{l^{-1}}$, but may range from 100 to 5000 ueq $\mathrm{l}^{-1}$ (Stumm \& Morgan 1996), so the equilibrium $\mathrm{pH}$ versus salinity relationship would be different in other estuaries. As the alkalinity of the oceanic end member of estuarine mixing gradients varies little, the equilibrium $\mathrm{pH}$ for the higher salinity portions of estu- aries will most often be in the 8.0 to 8.2 range. Temperature effects on $\mathrm{pH}$ are relatively small. An increase of $20^{\circ} \mathrm{C}$ in seawater will decrease $\mathrm{pH}$ only by about 0.07 (at constant $\mathrm{ppCO}_{2}$ and $30 \%$ ).

The gradient in equilibrium $\mathrm{pH}$ along a salinity gradient may be one factor that controls the appearance of different phytoplankton species along the salinity gradient. However, the focus of this review is the effect of variability in $\mathrm{pH}$ at a particular salinity or at a locale with a relatively narrow range in salinity. In Delaware Bay (Fig. 1), the observed pH values are up to 1.0 units below and 0.6 units above the equilibrium $\mathrm{pH}$ envelope.

Fig. 2 shows the observed $\mathrm{pH}$ and the equilibrium $\mathrm{pH}$ over time for a station in lower Narragansett Bay where the salinity ranges from about 29 to $31 \%$. Here, the observed $\mathrm{pH}$ is 0.5 units above or below the equilibrium $\mathrm{pH}$ at different times of the year. Where the $\mathrm{pH}$ deviates from equilibrium $\mathrm{pH}$, the partial pressure of $\mathrm{CO}_{2}$ in the water is correspondingly out of equilibrium with atmospheric $\mathrm{CO}_{2}$.

Changes in alkalinity and temperature are reflected in the calculated equilibrium pH in Figs. 1 \& 2. Hence, the deviations from the equilibrium $\mathrm{pH}$ are primarily caused by the metabolic processes of photosynthesis and respiration removing or injecting $\mathrm{CO}_{2}$, respectively, from or to the water. $\mathrm{CO}_{2}$ is taken up during plant growth, causing the $\mathrm{pH}$ to rise, and is released to water during respiration, causing the $\mathrm{pH}$ to fall. Fig. 3 shows the relationship between $\mathrm{pH}$ and total $\mathrm{CO}_{2}$ concentrations for one set of conditions.

The alkalinity of seawater, and hence $\mathrm{pH}$, is also affected by the metabolic uptake and release of nutri-

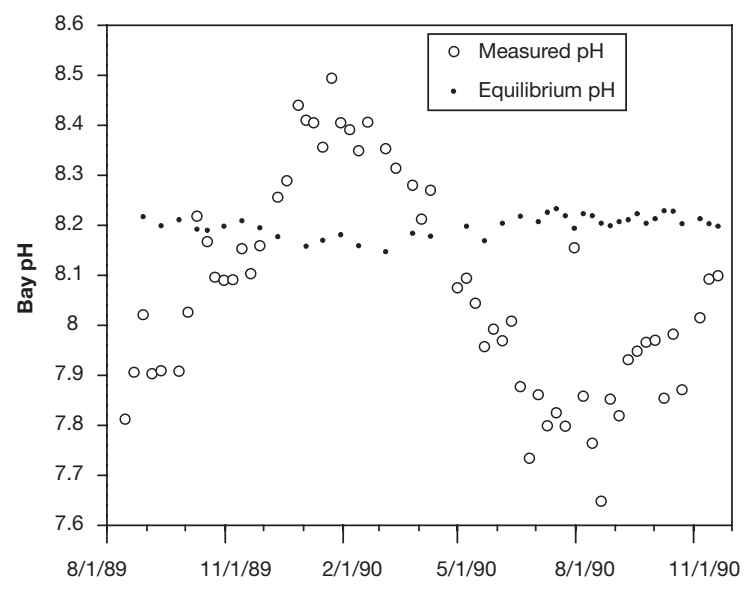

Fig. 2. Observed pH of seawater ( $(0)$ in Narragansett Bay at the Graduate School of Oceanography pier in lower Narragansett Bay (Hinga 1992). Salinity at this location is 28 to $31 \%$. The equilibrium $\mathrm{pH}(\bullet)$ was calculated for each sample from the measured alkalinity and temperature, and a $\mathrm{CO}_{2}$ partial pressure of $352 \mu \mathrm{atm}$ and salinity of $30 \%$. Dates are mo/d/yr 


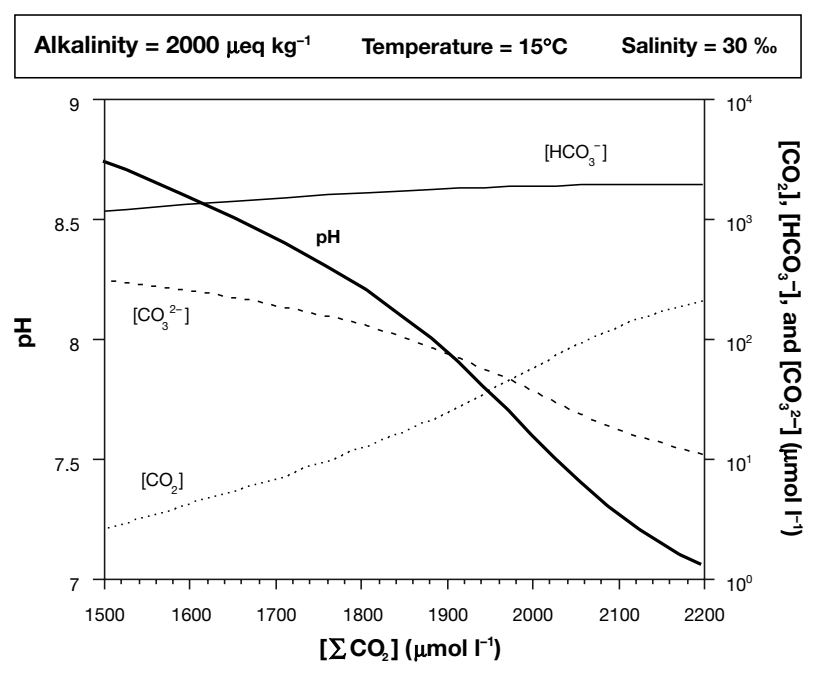

Fig. 3. Total $\mathrm{CO}_{2}$ versus $\mathrm{pH}$ and concentration of $\mathrm{CO}_{2}$ species. Concentrations and $\mathrm{pH}$ were calculated using the equations and constants from Skirrow (1975), Weiss (1974) and Plath et al. (1980)

ents, especially the $\mathrm{N}$ nutrients (Stumm \& Morgan 1996). Uptake of $\mathrm{NH}_{4}{ }^{+}$decreases the alkalinity and lowers the $\mathrm{pH}$. Uptake of $\mathrm{NO}_{3}{ }^{-}$increases alkalinity and raises pH. Fig. 4 shows the effect of alkalinity changes on $\mathrm{pH}$ and $\mathrm{CO}_{2}$ concentrations.

Assuming a Redfield ratio for $\mathrm{C}$ and nutrients during respiration and plant growth, the changes in $\mathrm{pH}$ resulting from changes in total $\mathrm{CO}_{2}$ can be considerably greater than the $\mathrm{pH}$ changes resulting from the proportional changes in alkalinity. This excludes anoxic conditions and conditions where precipitation of calcium carbonate $\left(\mathrm{CaCO}_{3}\right)$ takes place. Table 1 shows the case of a bloom resulting in the removal of $200 \mu \mathrm{mol} \mathrm{CO}{ }_{2}, 29 \mu \mathrm{mol} \mathrm{N}$ as either $\mathrm{NO}_{3}{ }^{-}$or $\mathrm{NH}_{4}{ }^{+}$and $1.9 \mu \mathrm{mol} \mathrm{PO}_{4}{ }^{3-}$ from $1 \mathrm{l}$ water. The results are provided for 2 conditions: (1) allowing no $\mathrm{CO}_{2}$ exchange with the atmosphere; and (2) after re-equilibration of $\mathrm{CO}_{2}$ with the atmosphere.

With an initial $\mathrm{pH}$ of 8.17, and with no exchange with the atmosphere, the decrease in $\mathrm{CO}_{2}$ concentration drives the $\mathrm{pH}$ up by $0.40 \mathrm{pH}$ units to 8.57 (Fig. 3). In comparison, the uptake of $\mathrm{NO}_{3}{ }^{-}$and $\mathrm{PO}_{4}{ }^{3-}$ in the Redfield ratio to $\mathrm{C}$ uptake increases the alkalinity 35 ueq which causes a pH increase of only 0.077 (Fig. 4). Similar calculations can be found in Pruder \& Bolton (1979), Stumm \& Morgan (1996), and Goldman (1999). An example of nutrient decrease and $\mathrm{pH}$ rise over time in a marine enclosure may be seen in McAllister et al. (1961). If the bloom was supported by $\mathrm{NH}_{4}{ }^{+}$instead of $\mathrm{NO}_{3}{ }^{-}$, the alkalinity would have decreased by $23 \mu$ eq (i.e. the net result of $29 \mu$ eq from $\mathrm{NH}_{4}{ }^{+}$and $\sim 6$ eeq from $\mathrm{PO}_{4}{ }^{3-}$ ) and the $\mathrm{pH}$ decreased

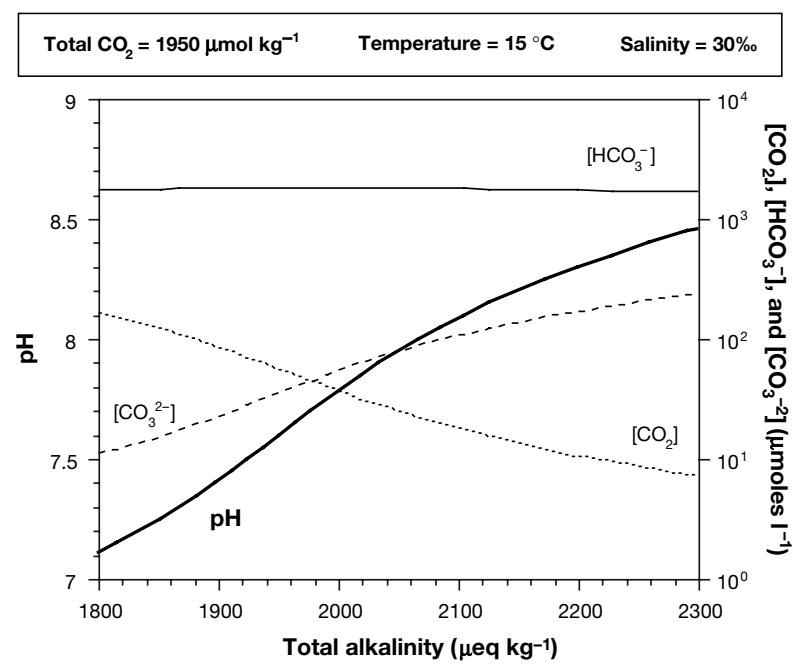

Fig. 4. Alkalinity vs $\mathrm{pH}$ and $\mathrm{CO}_{2}$ species. See Fig. 3 legend

by 0.056 . Any bloom supported by a combination of $\mathrm{NO}_{3}{ }^{-}$and $\mathrm{NH}_{4}{ }^{+}$will have even smaller alkalinity driven effects on $\mathrm{pH}$. After equilibration with the atmosphere, the $\mathrm{pH}$ change would only be that resulting from the alkalinity changes. It should be recognized that in a coastal environment, the highest concentration of plant $\mathrm{C}$ observed does not necessarily comprise all the inorganic $C$ that has been recently removed from the seawater. Grazers and settling may remove significant portions of phytoplankton $\mathrm{C}$ that may not be immediately remineralized and transported from the waters containing the bloom (e.g. Rudnick \& Oviatt 1986).

The magnitude of the $\mathrm{pH}$ change actually achieved in the seawater due to removal or injection of $\mathrm{CO}_{2}$ by organism metabolism depends upon the rates of

Table 1. Changes in $\mathrm{pH}$ from phytoplankton growth with nutrients and $\mathrm{CO}_{2}$ in the Redfield ratio. For a bloom which consumes: $1.9 \mu \mathrm{mol} \mathrm{kg}{ }^{-1} \mathrm{PO}_{4}{ }^{3-}, 29 \mu \mathrm{mol} \mathrm{kg}{ }^{-1} \mathrm{NO}_{3}{ }^{-}$or $\mathrm{NH}_{4}{ }^{+}$, and $200 \mu \mathrm{mol} \mathrm{kg}{ }^{-1}$ total $\mathrm{CO}_{2}$, the following changes in seawater $\mathrm{pH}$ will occur before and after equilibration with the atmosphere. The initial conditions are $\mathrm{pH}=8.17$, alkalinity $=$

$2000 \mu \mathrm{eq} \mathrm{kg}^{-1}$, salinity $=30 \%$ and temperature $=15^{\circ} \mathrm{C}$

\begin{tabular}{|lccc|}
\hline $\begin{array}{l}\text { Alkalinity } \\
\text { change } \\
\left(\mu \mathrm{eq} \mathrm{kg}^{-1}\right)\end{array}$ & $\begin{array}{c}\text { Total } \mathrm{CO}_{2} \\
\text { change } \\
\left(\mu \mathrm{mol} \mathrm{kg}{ }^{-1}\right)\end{array}$ & $\begin{array}{c}\mathrm{pH} \text { change } \\
\text { initial }\end{array}$ & $\begin{array}{c}\mathrm{pH} \text { change } \\
\text { after } \\
\text { equilibration }\end{array}$ \\
\hline$+35\left(\mathrm{NO}_{3}^{-}\right)$ & 0 & +0.077 & +0.007 \\
$-23\left(\mathrm{NH}_{4}{ }^{+}\right)$ & 0 & -0.056 & -0.004 \\
0 & -200 & +0.40 & 0 \\
+35 & -200 & +0.44 & +0.007 \\
-23 & -200 & +0.36 & -0.004 \\
\hline
\end{tabular}




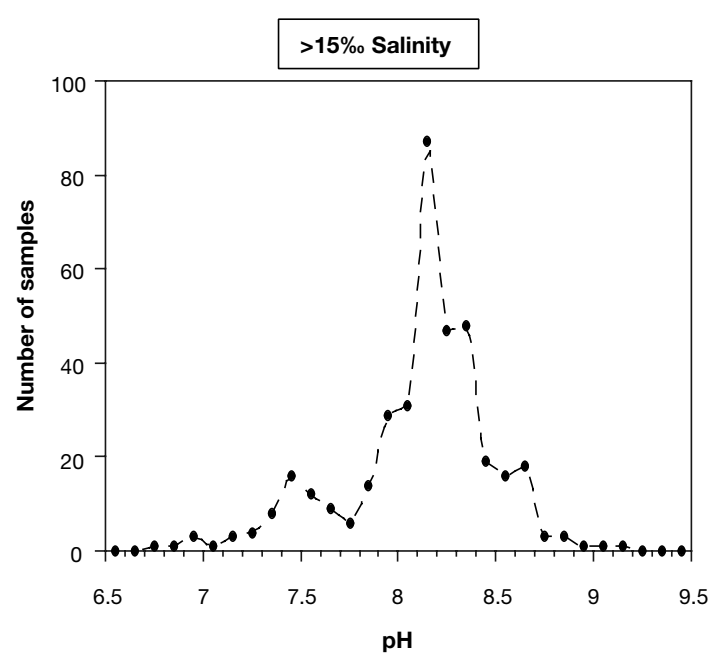

Fig. 5. Number of $\mathrm{pH}$ measurements in each 0.1 interval for the lower Chesapeake Bay between 1957 and 1963. Data is from Hires et al. (1963) and data reports cited therein

metabolic input or removal of $\mathrm{CO}_{2}$ relative to the rate the body of water equilibrates with the atmosphere. The magnitude of metabolically driven changes in $\mathrm{CO}_{2}$ concentration, and therefore variations in $\mathrm{pH}$, depends on whether a body of water is quiescent or rapidly stirred by wind and waves so as to allow air-sea exchange to proceed quickly. For the Delaware Bay and Narragansett Bay examples shown in Figs. 1 \& 2, it is clear that the metabolic processes are fast enough relative to equilibration with the atmosphere to achieve considerable disequilibrium.

\section{Seawater $\mathrm{pH}$ in coastal environments}

It is useful to examine the variability of $\mathrm{pH}$ in a few additional coastal environments to establish the range in $\mathrm{pH}$ that is found, and the frequency of different magnitude deviations from equilibrium $\mathrm{pH}$. A series of surveys reported by Hires et al. (1963) provides a description of the $\mathrm{pH}$ variability in the Chesapeake Bay. Contours of $\mathrm{pH}$ indicated a patchy distribution of $\mathrm{pH}$ in the bay. During each of the 24 complete surveys (each taken over $3 \mathrm{~d}$ ), there was a minimum difference of $1 \mathrm{pH}$ unit between high and low patches of water (i.e. the difference in contour, not the difference between the absolute minimum and maximum measurements). The maximum difference during a single survey was $2 \mathrm{pH}$ units between the highest and lowest contours. The estuarine gradient in equilibrium $\mathrm{pH}$ and seasonal temperature variability can only account for about 0.3 units of this variability.

Fig. 5 provides another view of the $\mathrm{pH}$ variability for surface waters of lower Chesapeake Bay. The most frequent measurements are near $\mathrm{pH} 8.0$ to 8.2 , as would be expected for seawater in equilibrium with the atmosphere. However, there are many measurements having $\mathrm{pH}$ well above and below the median $\mathrm{pH}$. Table 2 provides a single statistic to quantify the $\mathrm{pH}$ variability in some coastal waters. The statistic is the fraction of samples that are $\geq 0.5$ units either above or below the median $\mathrm{pH}$ for that system. In all but 1 case, more than $10 \%$ of the samples were $\geq 0.5$ units from the median $\mathrm{pH}$. In small isolated bodies of water, $\mathrm{pH}$ extremes can be still greater (Skirrow 1975). Examples of rather large deviations from equilibrium $\mathrm{pH}$ have also been reported for less-confined coastal waters. Pegler \&

Table 2. The distribution of surface water $\mathrm{pH}$ in estuarine environments. For Chesapeake Bay, the data was sorted by salinity so that only the $\mathrm{pH}$ of samples between the stated salinity values were included. The STORET data was selected by specifying an area. Areas were chosen to correspond to the average salinity conditions listed

\begin{tabular}{|c|c|c|c|c|c|}
\hline $\begin{array}{r}\text { Perce } \\
\text { from }\end{array}$ & $\begin{array}{l}\text { nt of samples } \\
\geq 0.5 \mathrm{pH} \\
\text { median pH }\end{array}$ & $\begin{array}{l}\text { Median } \\
\text { pH }\end{array}$ & $\begin{array}{l}\text { No. of } \\
\text { samples }\end{array}$ & $\begin{array}{l}\text { Salinity } \\
(\% \circ)\end{array}$ & Years covered and source \\
\hline Lower Chesapeake Bay & 18.0 & 8.2 & 383 & 15 to 30 & $\begin{array}{l}\text { 1957-1963 Hires et al. (1963) and data } \\
\text { reports cited therein }\end{array}$ \\
\hline \multicolumn{6}{|l|}{ Tampa Bay (3 regions) } \\
\hline Central & 12.7 & 8.0 & 10890 & $>25$ & \multirow[t]{3}{*}{ EPA STORET System ${ }^{\mathrm{a}} 1980$ to 1990} \\
\hline Hillsborough Bay & 23.8 & 7.9 & 3832 & 5 to 25 & \\
\hline Old Tampa Bay & 14.7 & 7.9 & 3918 & 5 to 25 & \\
\hline \multirow[t]{3}{*}{ Delaware Bay } & 32.8 & 7.8 & 813 & 5 to 25 & EPA STORET System ${ }^{\mathrm{a}} 1980$ to 1990 \\
\hline & 14.1 & 7.8 & 498 & 5 to 25 & U. of Delaware Data Reports (see Fig. 1) \\
\hline & 1.0 & 8.0 & 293 & $>25$ & U. of Delaware Data Reports (see Fig. 1) \\
\hline Tybee Creek (Savannah River) & 18.8 & 7.5 & 85 & $>25$ & 1973-1974 Winker et al. (1985) \\
\hline Puget Sound & 11.3 & 7.9 & 5541 & $>25$ & EPA STORET System ${ }^{\mathrm{a}} 1980$ to 1990 \\
\hline
\end{tabular}


Kempe (1988) reported a survey in May/June 1986 finding a band of water with $\mathrm{pH} \geq 8.5$ extending approximately $300 \mathrm{~km}$ along the North Sea coast from the Danish-German border to the western extent of the Waddenzee in the Netherlands. In 1993, Brussaard et al. (1996) observed the $\mathrm{pH}$ of water entering the Marsdiep tidal inlet from the North Sea rise from $\mathrm{pH} 7.9$ in late March to $\mathrm{pH} 8.7$ by late April.

The $\mathrm{pH}$ of coastal environments has probably been altered through nutrient enrichment. Human activities have lead to a global doubling of $\mathrm{N}$ and $\mathrm{P}$ concentrations in river waters and increases of 10 to 50 times over natural levels in rivers in industrialized areas (Meybeck 1982). The increased delivery of nutrients to the coastal zone has led to easily observable increases (i.e. doublings) of nutrient concentrations and phytoplankton abundance within coastal waters. A few examples include Chesapeake Bay (Harding 1994, Price et al. 1985), the Mississippi plume (Eadie et al. 1994), the Baltic (Nehring et al. 1984, Rosenberg et al. 1990), the German Bight area of the North Sea (Gerlach 1990), and Tolo Harbor, Hong Kong (Hodgkiss \& Chan 1987).

When more nutrients are available, larger blooms may be supported which drive $\mathrm{pH}$ to progressively higher levels. Nutrient-enriched environments may lead to more sustained removal of inorganic $\mathrm{C}$ from seawater and sequestration of $\mathrm{C}$ in sediments, which is later remineralized; thus, driving any seasonal $\mathrm{pH}$ cycle, or simply temporal $\mathrm{pH}$ variability, to a greater amplitude.

An example of such an effect is shown in Fig. 6 for a 28 mo eutrophication experiment. This study was carried out in $13 \mathrm{~m}^{3}$ outdoor marine enclosures of the Marine Ecosystems Research Laboratory (MERL; Nixon et al. 1984, Kelly et al. 1985, Oviatt et al. 1986a,b, 1989, Keller 1988a,b, 1989, Keller \& Rice 1989, Hinga 1990). Enclosures treated daily with moderate amounts of $\mathrm{N}$ and $\mathrm{P}$ had an amplified seasonal $\mathrm{pH}$ range. Control enclosures without nutrient additions had a seasonal pH cycle similar to that for lower Narragansett Bay, shown in Fig. 2. There are limits as how high the $\mathrm{pH}$ cycle can be amplified by nutrient enrichment. In enclosures treated with very high loadings of nutrients, the regular annual cycles of production and $\mathrm{pH}$ found in the control enclosures were no longer evident.

An amplification of $\mathrm{pH}$ range upon eutrophication was also found in experiments in brackish experimental coastal ponds (salinity approximately 18\%) reported by Laughinghouse \& Kuenzler (1971). Control ponds had a short-term (over a few weeks) $\mathrm{pH}$ variability of about $0.5 \mathrm{pH}$ unit and only exceeded the range of 7.5 to 8.5 once over 10 mo. The ponds given nutrient additions had a short-term $\mathrm{pH}$ variability of about $1.0 \mathrm{pH}$ unit and varied from 7.5 to 10.5 over the 10 mo experiment.

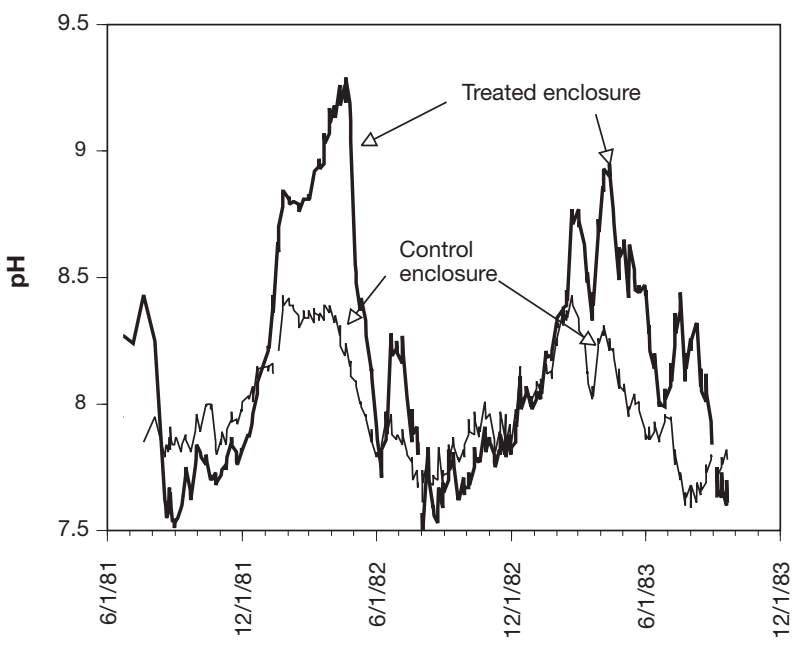

Fig. 6. $\mathrm{pH}$ in a control and a nutrient-treated marine enclosure at the Marine Ecosystems Research Laboratory of the University of Rhode Island. Both enclosures had water exchange with Narragansett Bay (low nutrient water) at a nominal rate of $4 \% \mathrm{~d}^{-1}$. The treated tank (the $4 \times$ treatment) had daily additions of 2.3 , 0.18 and $0.17 \mu \mathrm{mol} \mathrm{l}^{-1} \mathrm{~d}^{-1}$ of $\mathrm{NH}_{4}{ }^{+}, \mathrm{PO}_{4}{ }^{3-}$ and silicate, respectively. The control enclosure had total inorganic $\mathrm{N}$ concentrations in the range 1 to $10 \mu \mathrm{mol}^{-1}$. The treated tank had total inorganic $\mathrm{N}$ concentrations typically between 40 and $80 \mu \mathrm{mol} \mathrm{l}^{-1}$.

The data is from Frithsen et al. (1985). Dates are mo/d/yr

It is difficult to generalize a $\mathrm{pH}$ response to eutrophication for all coastal ecosystems. Additions of metabolizable organic matter often accompany additions of nutrients. Remineralization of the organic matter may tend to push the $\mathrm{pH}$ lower through the generation of $\mathrm{CO}_{2}$. The net result of additions of organic matter and nutrients on $\mathrm{pH}$ in different environments will depend on the ratios of nutrients to organic $\mathrm{C}_{\text {, the form of the }}$ $\mathrm{C}$, the hydrodynamics of the local environment, the background suspended load of sediments and the response of organisms, including the phytoplankton.

There is an additional small effect on seawater $\mathrm{pH}$ that results from anthropogenic modification of the atmosphere. Since pre-industrial times to the present, the atmospheric concentration of $\mathrm{CO}_{2}$ has risen from approximately 290 to $360 \mu \mathrm{atm}$. This change has lowered the equilibrium $\mathrm{pH}$ of seawater about 0.1 units (Pilson 1998).

\section{Experimental manipulation of $\mathrm{pH}$}

It is not possible to manipulate $\mathrm{pH}$ without also affecting some of the other components of seawater (e.g. Figs. $3 \& 4$ ). A variety of techniques can be used to establish the range of $\mathrm{pH}$. It is important to understand the ramifications of the type of $\mathrm{pH}$ control approach used in different studies. All the studies listed in this 


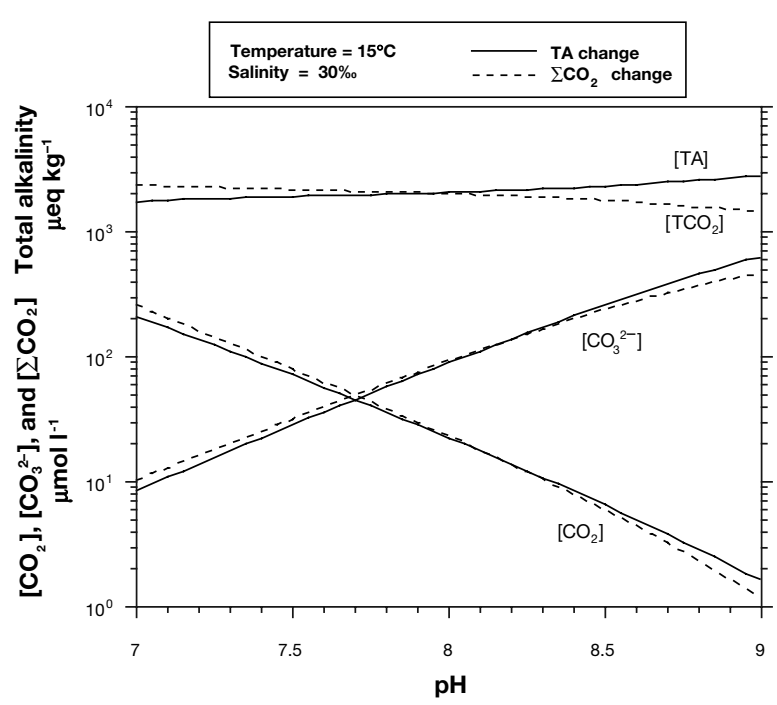

Fig. 7. Comparison of the $\mathrm{pH}$ and free $\mathrm{CO}_{2}$ and carbonate relationships for alkalinity and total $\mathrm{CO}_{2}$ driven changes in $\mathrm{pH}$. In the case of constant $\mathrm{CO}_{2}$, the total $\mathrm{CO}_{2}$ was $1950 \mu \mathrm{mol}$ $\mathrm{l}^{-1}$ In the case of constant total alkalinity, the total alkalinity was $2148 \mu \mathrm{eq} \mathrm{l}^{-1} \mathrm{~A}$ parcel of seawater starting from these conditions (and at $30 \%$ and $15^{\circ} \mathrm{C}$ ) that is changed to $\mathrm{pH} 9$ by $\mathrm{CO}_{2}$ removals will have $1.18 \mu \mathrm{mol} \mathrm{kg}{ }^{-1}$ free $\mathrm{CO}_{2}$. The same parcel of seawater if changed from $\mathrm{pH} 8$ to 9 by addition of a strong base will have $1.60 \mu \mathrm{mol} \mathrm{\textrm {kg } ^ { - 1 }}$ free $\mathrm{CO}_{2}$. Changing the initial parcel of water to $\mathrm{pH} 7$ by $\mathrm{CO}_{2}$ injections will result in a free $\mathrm{CO}_{2}$ concentration of $260 \mu \mathrm{mol} \mathrm{kg}{ }^{-1}$ at $\mathrm{pH} 9$ while making the same $\mathrm{pH}$ change with the addition of strong acid will result in a free $\mathrm{CO}_{2}$ concentration of $212 \mu \mathrm{mol} \mathrm{kg}{ }^{-1}$. The additions of acid or base (e.g. $\mathrm{HCl}$ or $\mathrm{NaOH}$ ) to achieve this range of $\mathrm{pH}$ will change the concentrations of the major ions (e.g. $\mathrm{Na}^{+}$or $\mathrm{Cl}^{-}$) in $30 \%$ seawater in the order of $0.1 \%$

review demonstrate some $\mathrm{pH}$ effect on phytoplankton. The approach used to control pH may: (1) simulate field conditions; (2) not simulate field conditions but may provide insight into the mechanism of a $\mathrm{pH}$ effect; (3) approximate field conditions; or (4) solely demonstrate a $\mathrm{pH}$ effect (under conditions that do not replicate or simulate field conditions nor provide insight into mechanisms of the effect).

The concentrations of some of the dissolved components in seawater, including those of free $\mathrm{CO}_{2}$, carbonate $\left(\mathrm{CO}_{3}{ }^{2-}\right)$ and bicarbonate $\left(\mathrm{HCO}_{3}{ }^{-}\right)$, co-vary with $\mathrm{pH}$. The $\mathrm{pH}$ drift experiments of Goldman (1999) and one experiment by Pruder \& Bolton (1979) closely simulate the way $\mathrm{pH}$ change occurs in coastal environments, through injections and removals of $\mathrm{CO}_{2}$. The behavior of species in these experiments should closely simulate the results expected in the field.

In a second type of experimental conditions, both the alkalinity and one other component of the seawater $\mathrm{pH}$-carbonate system were manipulated. Here, the concentration of one component of the carbonate system, free $\mathrm{CO}_{2}$ was held constant across a range of $\mathrm{pH}$. This was achieved by bubbling a gas mixture through the culture with a set fraction of $\mathrm{CO}_{2}$, so as to maintain a constant concentration of free $\mathrm{CO}_{2}$ in the water of each culture. In these experiments, the normal relationship between $\mathrm{pH}$ and free $\mathrm{CO}_{2}$ is not found. While these experiments do not simulate field conditions, they do help determine if observed $\mathrm{pH}$ effects (at high $\mathrm{pH}$ ) are caused by limiting concentrations of free $\mathrm{CO}_{2}$.

A third type of experiment used an alkalinity adjustment (usually additions of strong acid or base) to achieve the desired $\mathrm{pH}$. This approach gives conditions that approximate the relationship between $\mathrm{pH}$ and the dissolved $\mathrm{CO}_{2}$ species that results from additions or removals of $\mathrm{CO}_{2}$. For both $\mathrm{CO}_{2}$ and alkalinity driven $\mathrm{pH}$ adjustment, at high $\mathrm{pH}$ there is low free $\mathrm{CO}_{2}$ and at low $\mathrm{pH}$ there is high free $\mathrm{CO}_{2}$ (see Fig. 7). However, the specific concentrations of the dissolved $\mathrm{CO}_{2}$ species differ slightly between alkalinity adjustment and total $\mathrm{CO}_{2}$ adjustment ( 20 to $25 \%$ at $\mathrm{pH} 7$ or 9). If a $\mathrm{pH}$ effect is the result of growth limitation by the availability of free $\mathrm{CO}_{2}$, the magnitude of the effect (at a specific $\mathrm{pH}$ ) determined by alkalinity adjustment may differ slightly from the growth rate at a given $\mathrm{pH}$ caused by total $\mathrm{CO}_{2}$ change.

Where the adjustment of $\mathrm{pH}$ was attempted by simply adding acid or base, the change in alkalinity shifts the partial pressure of $\mathrm{CO}_{2}$ out of equilibrium with the atmosphere. While the initial $\mathrm{pH}$ may have been at a desired level, cultures exposed to the atmosphere tended to drift back to the initial $\mathrm{pH}$ as the $\mathrm{CO}_{2}$ in the

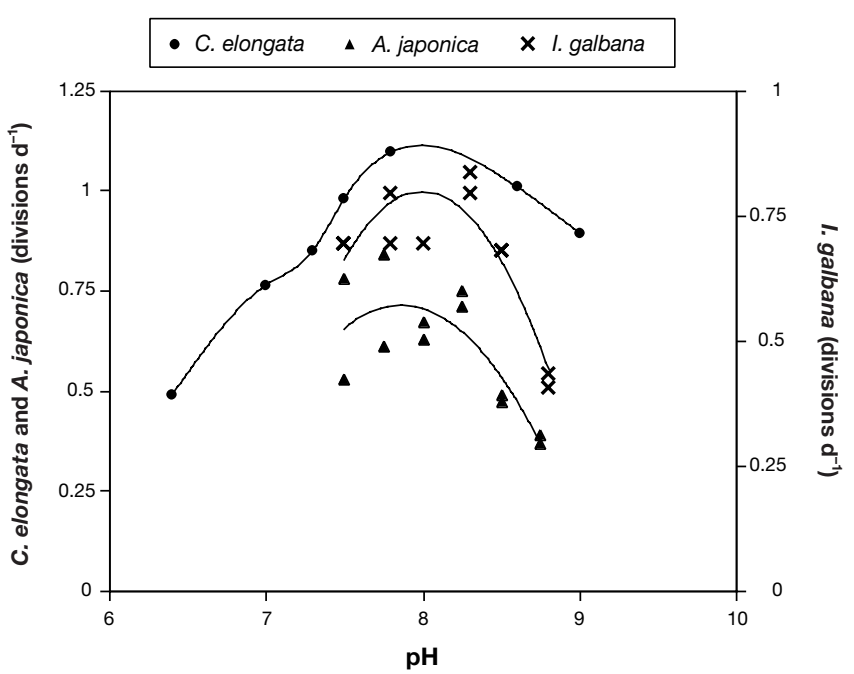

Fig. 8. Cricosphaera elongata (Swift \& Taylor 1966), Asterionella japonica (Kain \& Fogg 1958a) and Isochrysis galbana (Kain \& Fogg 1958b). Growth rates in laboratory cultures. $C$. elongata: average values of 2 to 16 replicate cultures. C. elongata at $\mathrm{pH} 6.4,7.0$ and 7.5 were cultured with air enriched to $5 \% \mathrm{CO}_{2}$ and at the remaining $\mathrm{pH}$ with air at $0.03 \% \mathrm{CO}_{2}$. Curve fits are interpolation for $C$. elongata and 2nd degree polynomial for A. japonica and I. galbana 


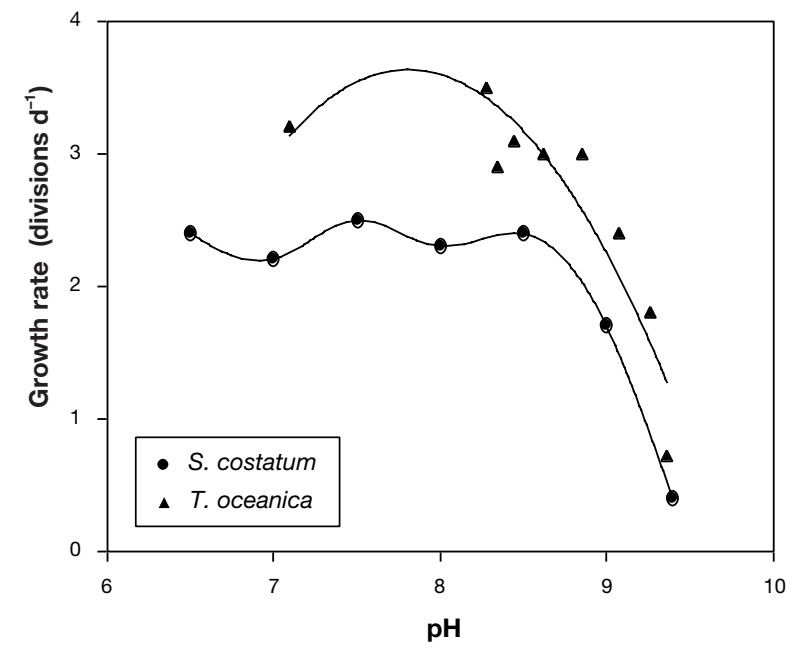

Fig. 9. Thalassiosira oceanica (Chen 1986, Chen \& Durbin 1994) and Skeletonema costatum (Taraldsvik \& Myklestad 2000). Growth rates in laboratory cultures. Curve fits are 2nd degree polynomial for $T$. oceanica and interpolation for $S$. costatum. Values for $S$. costatum are the average of 3 cultures

cultures re-equilibrated with the atmosphere. This non-constant $\mathrm{pH}$ occurred especially in some of the earlier studies.

As an example, the addition of 0.35 meq $\mathrm{l}^{-1}$ of strong acid will drive the $\mathrm{pH}$ of seawater from $\mathrm{pH} 8.1$ to $\mathrm{pH} 7$. This also results in a large excess partial pressure of $\mathrm{CO}_{2}$ relative to the atmosphere. The cultures would lose $\mathrm{CO}_{2}$ to the atmosphere (and likely to uptake by phytoplankton). Upon complete $\mathrm{CO}_{2}$ re-equilibration with the atmosphere, the culture would re-stabilize at $\mathrm{pH}$ 8.04. In such experiments, the $\mathrm{pH}$ was constantly changing. In some studies, the $\mathrm{pH}$ was held relatively constant against $\mathrm{pH}$ drift by repetitive additions of acid or base. In experiments where short-term measurements were made, there was usually insufficient time for $\mathrm{pH}$ to drift appreciably.

In a fourth general approach, a buffer was added to the seawater (Kain \& Fogg 1958a,b, Griffis \& Chapman 1990) and the alkalinity adjusted. The buffer adds an additional component that participates in the acidbase reactions in the relevant $\mathrm{pH}$ range. Hence, the normal relationship between $\mathrm{pH}$ and other seawater components (such as free $\mathrm{CO}_{2}$ ) may not be found. If the mechanism of the $\mathrm{pH}$ effect found for the species in these experiments is related to the concentrations of the normal $\mathrm{pH}$-sensitive components of seawater (other than the hydrogen ion concentration itself), then the $\mathrm{pH}$ effect may not be the same as would be found in a $\mathrm{CO}_{2}$ driven $\mathrm{pH}$ change. Experiments under conditions that more closely simulate normal seawater conditions will be needed to see if the observed effect from this type of experiment is relevant to field conditions.
A note of caution should be added. Many of the laboratory studies have few data points with $1.0 \mathrm{pH}$ unit or more difference between treatments. In these cases, neither the $\mathrm{pH}$ for maximum growth nor the response to variable $\mathrm{pH}$ is well constrained within the range of $\mathrm{pH}$ usually expected in coastal ecosystems. The interpretation of many of the experiments could change considerably with the omission or movement of individual points. The few data points, and the scatter evident in some studies may suggest a $\mathrm{pH}$ for maximum growth or a response to $\mathrm{pH}$ change that is an imprecise reflection of the species or clone behavior. Without further experiments, it is impossible to identify results that are misleading. For the present, there is no option but to work with the data as reported and recognize that future work is necessary to clarify matters.

\section{Effects of seawater pH on phytoplankton}

Table 3 lists 21 individual or closely related studies containing information on the effects of $\mathrm{pH}$ on marine phytoplankton. Most of the studies were laboratory experiments that determined the effects of $\mathrm{pH}$ on growth rate, substrate uptake or the final population levels of populations after an incubation period. Two studies (Yoo 1991, Hinga 1992) found correlations between $\mathrm{pH}$ and abundance of dinoflagellates in mixed phytoplankton populations.

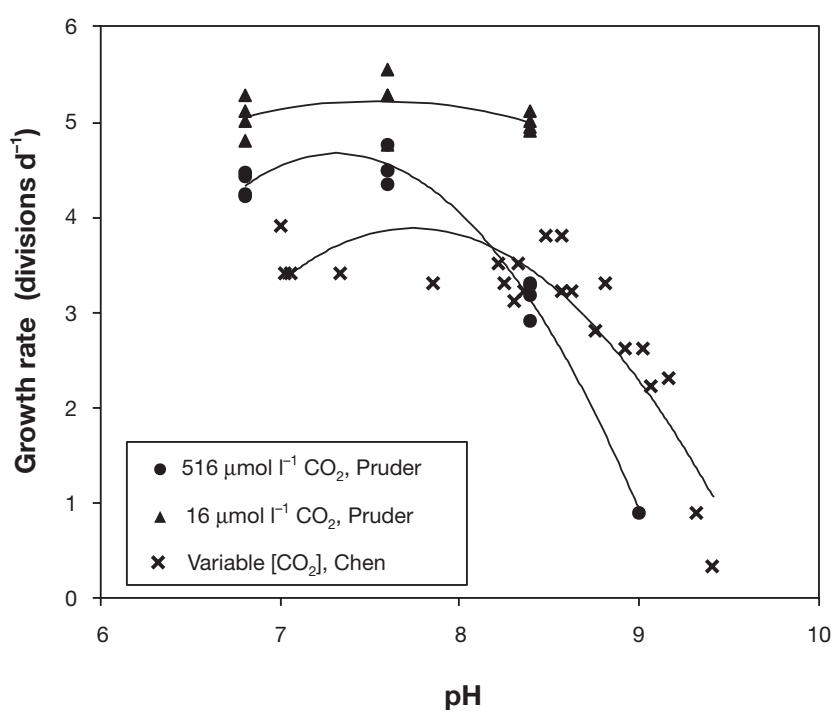

Fig. 10. Thalassiosira pseudonana. Growth rates in laboratory cultures. Pruder (1979): 2 free $\mathrm{CO}_{2}$ concentrations for 2 high light intensity treatments. The cultures at $\mathrm{pH} 9$ did not grow well and this point is an estimate of the average of an unspecified number of replicates. Curve fits are 2nd degree polynomials. Curve fit for the Chen (Chen 1986, Chen \& Durbin 1994) study is a 2nd degree polynomial 


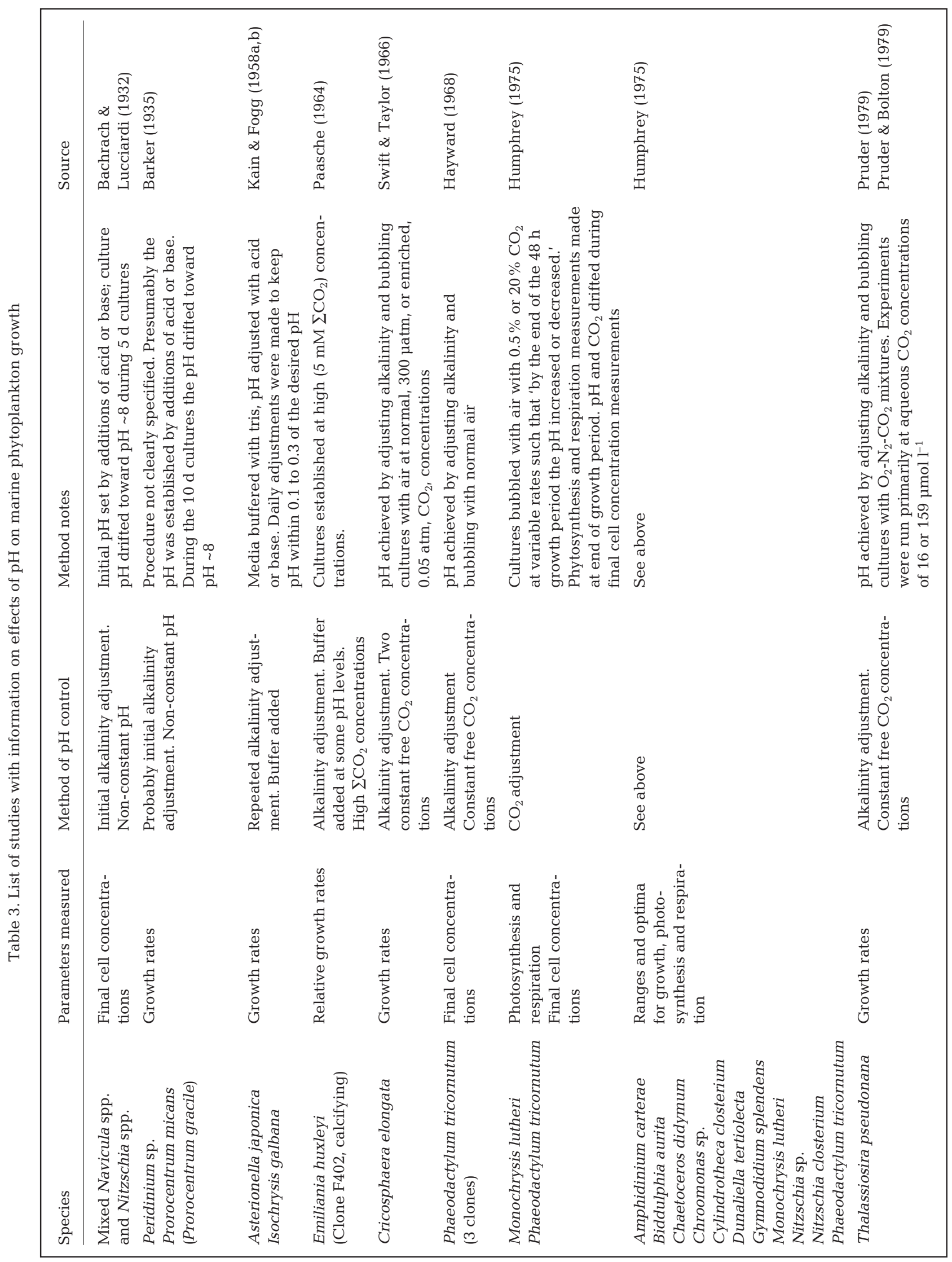




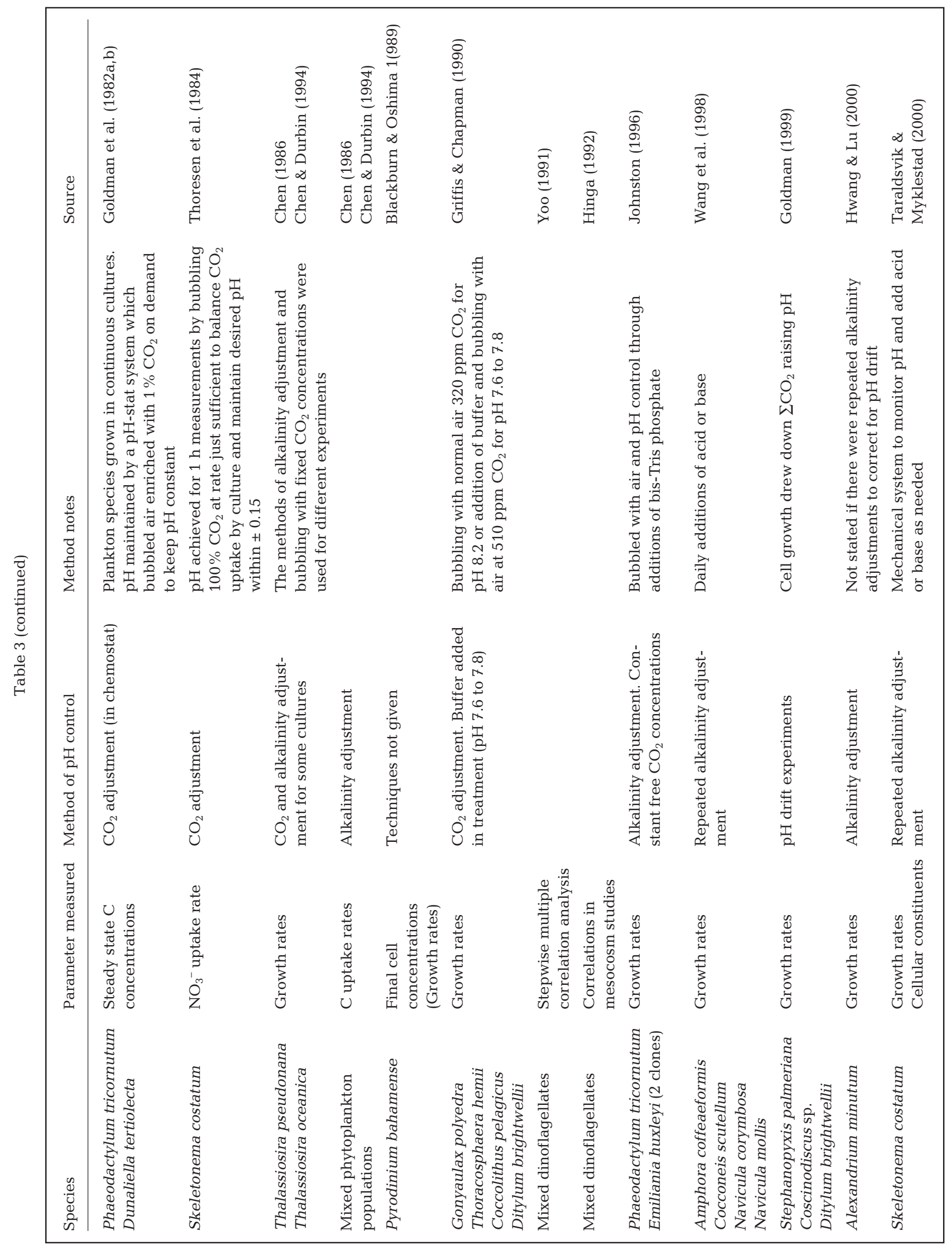




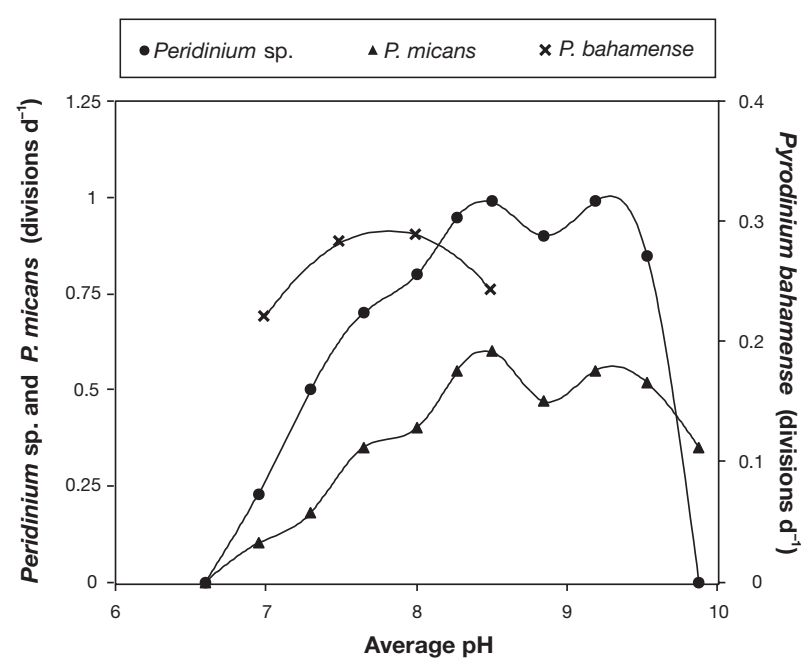

Fig. 11. Peridinium sp. and Prorocentrum micans. Growth rates from Barker (1935). The $\mathrm{pH}$ of the cultures drifted considerably during the experiments. Growth rates were plotted against the $\mathrm{pH}$ estimated to be halfway between the initial and final $\mathrm{pH}$. Pyrodinium bahamense. Growth rates (Blackburn \& Oshima 1989) calculated from initial and final population levels assuming exponential growth and no lag period. This provides a minimum growth rate estimate as any lag period after inoculation would require that the growth rate during log growth actually be greater than the minimum rate calculated. Curve fits are interpolations

The data suitable for graphical representation are replotted in Figs. 8 to 20 with a uniform pH scale. With 3 exceptions, each point shown in these figures represents the results from an individual culture or a single measurement. For Cricosphaera elongata in Fig. 8. (Swift \& Taylor 1966), for Skeletonema costatum in Fig. 9 (Taraldsvik \& Myklestad 2000) and one point for Thalassiosira pseudonana in Fig. 10 (Pruder 1979) each point represents the average value of replicate cultures.

Curve fits were made to each data set plotted in Figs. 8 to 20 to show the general trends of the data and to help distinguish the data for different species plotted in the same graph. The fits are not intended to represent functional relationships. The lines drawn from the curve fits were restricted to the range of the data. Curve-fit lines that extend to the edges of the graph indicate that there were data points above $\mathrm{pH} 10$ or below $\mathrm{pH}$ 6. Data from studies that were not appropriate for graphing are listed in Tables 4 \& 5 .

\section{pH for maximum growth}

Fig. 8 shows, for Cricosphaera elongata, Asterionella japonica and Isochrysis galbana, responses to $\mathrm{pH}$ that might be expected from the distribution of $\mathrm{pH}$ found in coastal seawater. Each of these species has maximum growth rate near equilibrium $\mathrm{pH}$. Their growth rates fall off progressively with higher or lower $\mathrm{pH}$. These 3 species should grow fastest at the most commonly occurring pH. Johnston (1996) found 2 clones of Emiliania huxleyi (Fig. 12) to have fastest growth near $\mathrm{pH}$ 8. The $\mathrm{C}$ uptake measurements in 5 different mixed phytoplankton populations (Chen 1986, Chen \& Durbin 1994) found maxima in C uptake rates at pH ranging from about 7.8 to 8.1 (Fig. 20).

Results for Skeletonema costatum in a study by Taraldsvik \& Myklestad (2000) indicate a broad region around equilibrium $\mathrm{pH}$ where the growth rate was nearly constant (Fig. 9). Above pH 8.5, the growth rate dropped off sharply. It should be noted that the concentration of cellular constituents did not have a similar broad plateau encompassing equilibrium $\mathrm{pH}$. The per cell content of $\beta-1,3$-glucan had a maximum at pH 8.0 and decreased markedly at higher and lower $\mathrm{pH}$. Also, the per cell concentration of total free amino acids was highest at $\mathrm{pH} 6.5$ to 7.0 and decreased with increasing $\mathrm{pH}$ up to $\mathrm{pH} 9.4$.

Thalassiosira oceanica (Fig. 9) and T. pseudonana (Fig. 10) from studies by Chen (1986) and Chen \& Durbin (1994) appear to exhibit a broad plateau of constant growth rate. Unfortunately, data are missing in the crucial range for T. oceanica. For T. pseudonana, the data indicate a plateau from approximately $\mathrm{pH} 7$ to 8.5 where the growth rate does not change with $\mathrm{pH}$. Results for T. pseudonana (Fig. 10) from Pruder (1979) at $\mathrm{CO}_{2}$ concentrations more representative of present

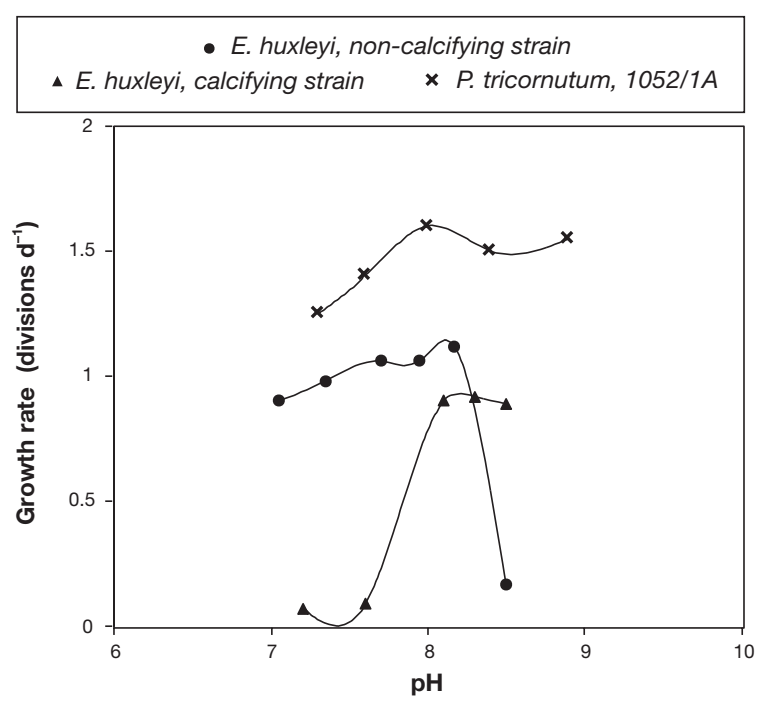

Fig. 12. Emiliania huxleyi (2 clones) and Phaeodactylum tricornutum. Growth rates from Johnston (1996). Curve fits are interpolations 


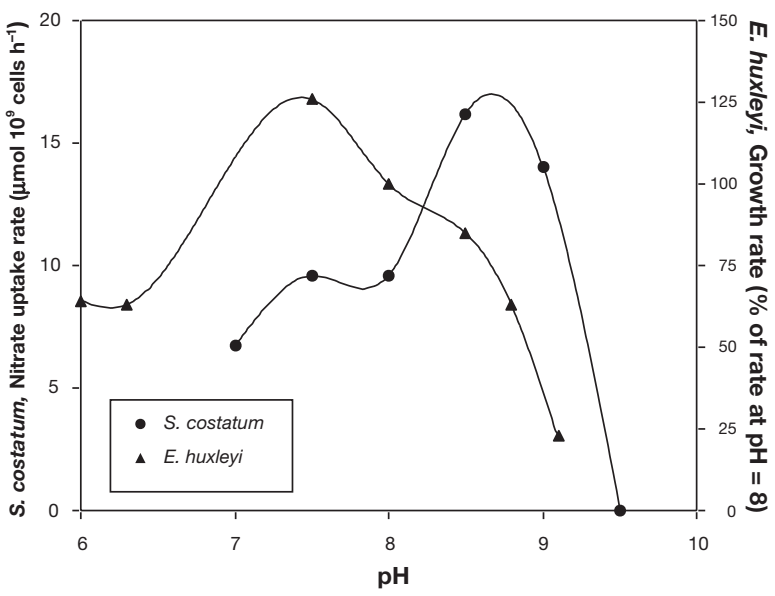

Fig. 13. Skeletonema costatum. Nitrate uptake rate (Thoresen et al. 1984). Emiliania huxleyi. Growth rate relative to growth rate at pH 8 (Paasche 1964). Curve fits are interpolations

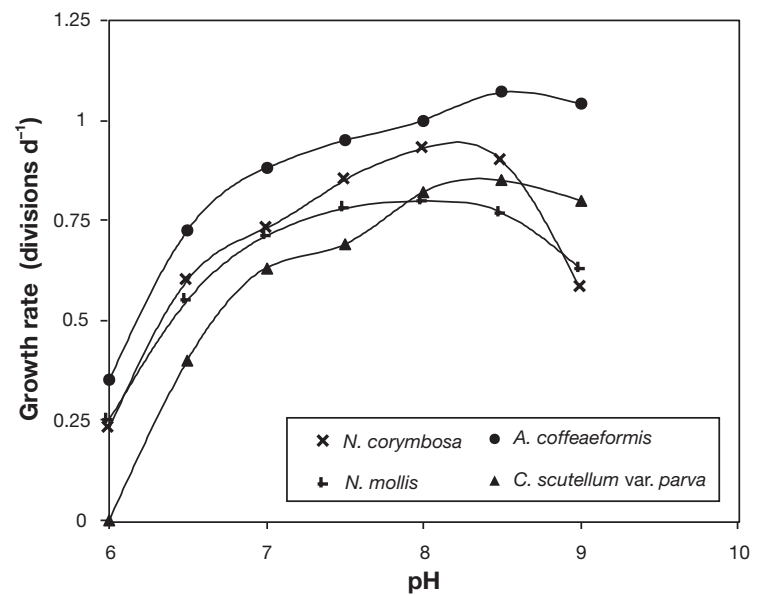

Fig. 14. Navicula corymbosa, Amphora coffeaeformis, N. mollis, and Cocconeis scutellum var. parva. Growth rates (Wang et al. 1998). Curve fits are interpolations day seawater $\left(16 \mu \mathrm{mol} \mathrm{l}^{-1}\right)$ also indicate little change in growth rate over a range of $\mathrm{pH} 6.8$ to 8.4. In an experiment where the $\mathrm{pH}$ was allowed to drift to higher values as the culture drew down the $\mathrm{CO}_{2}$, Pruder \& Bolton (1979) found that T. pseudonana grew at a constant rate until $\mathrm{pH} 8.8$ to 8.9 was reached, then stopped. Growth resumed in the culture upon the addition of acid and the lowering of the $\mathrm{pH}$. In similar $\mathrm{pH}$ drift experiments, Goldman (1999) found Stephanopyxis palmeriana, Coscinodiscus sp. and Ditylum brightwellii to have a constant growth rate from $\mathrm{pH} 8.1$ up to pH 8.45, 8.51 and 8.31, respectively. Above these values, the growth rates decreased. These experiments defined the point at high $\mathrm{pH}$ where growth rate slowed, but due to the nature of the drift experiments, the low $\mathrm{pH}$ limit of constant growth was not determined. Other examples of maximum growth rate being near equilibrium $\mathrm{pH}$ are the benthic diatoms Navicula corymbosa and Navicula mollis (Fig. 14) and Dunaliella tertiolecta (Fig. 15).

A number of species that appear to have fastest growth rates at low $\mathrm{pH}$ were reported by Humphrey (1975) and are listed in Table 4. Among those species is Monochrysis lutheri, which appears to have a maximum photosynthesis to respiration ratio and growth rate at $\mathrm{pH}$ about 7.5 (Figs. 16 \& 17). Paasche (1964) found a clone of Emiliania huxleyi (Fig. 13) to grow best at a pH of about 7.5 .

Table 4. Results reported by Humphrey (1975). Ranges for growth (defined as more than 1 division in $48 \mathrm{~h}$ ) and maxima are from Humphry's Fig. 3. Range tested and the $\mathrm{pH}$ at which the single highest values found are from Humphry's Table 1. A criteria for 'range in maxima' in cell concentration, photosynthesis, or P/R ratio is not given in the original paper. The original paper provided graphs of the data for Monochrysis lutheri and Phaeodactylum tricornutum (Figs. 16 \& 17 of this paper), but it is not clear how the range in maxima were defined. Results are based upon 5 cultures for each species

\begin{tabular}{|lccrr|}
\hline Species & $\begin{array}{c}\mathrm{pH} \text { ranges for growth } \\
\text { (Range tested) }\end{array}$ & $\begin{array}{c}\text { Maxima in cell } \\
\text { concentration } \\
\text { (pH at maximum value) }\end{array}$ & $\begin{array}{c}\text { Maxima in photo- } \\
\text { synthesis } \\
\text { (pH at maximum value) }\end{array}$ & $\begin{array}{c}\text { Maxima in P/R ratio } \\
\text { (pH at maximum value) }\end{array}$ \\
\hline Amphidinium carterae & $7.0-10.1(5.9-10.1)$ & $7.0-10.0(7.0)$ & $7.3-8.3(8.2)$ & $7.6-8.6(7.6)$ \\
Biddulphia aurita & $6.1-8.7(6.1-8.7)$ & $7.4-8.6(7.5)$ & $7.3-7.8(7.4)$ & $7.3-7.8(7.8)$ \\
Chaetoceros didymum & $7.0-9.0(5.7-9.0)$ & $7.3-9.0(7.5)$ & $7.3-8.8(7.5)$ & $7.3-7.9(7.2)$ \\
Chroomonas sp. & $7.0-9.0(6.1-9.5)$ & $7.5-9.3(8.1)$ & $7.4-7.7(7.5)$ & $7.4-7.7(7.5)$ \\
Cylindrortheia closterium & $5.9-8.5(5.9-9.9)$ & $6.4-8.3(7.3)$ & $6.0-7.7(7.4)$ & $6.9-7.9(7.6)$ \\
Dunaliella tertiolecta & $6.0-9.3(6.0-9.3)$ & $6.4-8.3(8.3)$ & $7.1-8.1(7.1)$ & $7.5-8.1(8.1)$ \\
Gymnodinium splendens & $7.0-8.9(6.1-8.9)$ & $7.3-8.0(7.3)$ & $7.4-7.7(7.6)$ & $7.3-7.8(7.5)$ \\
Monochrysis lutheri & $5.9-9.0(5.9-9.8)$ & $7.4-8.5(7.5)$ & $7.3-7.6(7.3)$ & $7.3-7.7(7.3)$ \\
Nitzschia closterium & $5.3-9.8(5.3-9.8)$ & $6.4-7.8(6.3)$ & $5.9-6.4(6.3)$ & $6.3-7.8(7.6)$ \\
Nitzschia sp. & $6.7-9.5(6.0-9.5)$ & $7.5-9.6(7.6)$ & $7.3-9.1(7.3)$ & $7.3-9.1(7.6)$ \\
Phaeodactylum tricornutum & $6.1-10.0(6.1-10.0)$ & $7.3-9.5(7.8)$ & $6.4-7.0 \& 9.4-10.0$ & $6.5-9.5(7.1)$ \\
\hline
\end{tabular}




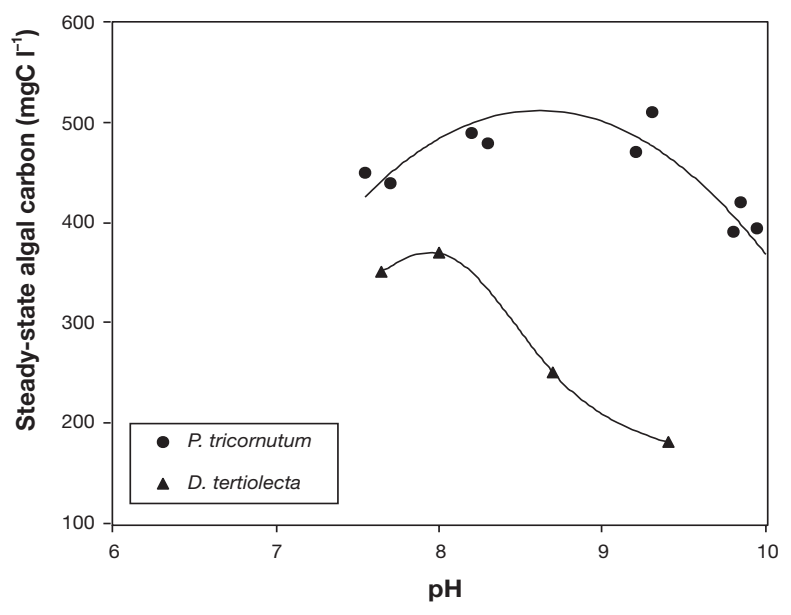

Fig. 15. Phaeodactylum tricornutum and Dunaliella tertiolecta grown in continuous cultures (Goldman et al. 1982a). Steady state algal C. Curve fit for $P$. tricornutum is a 2nd order polynomial. Curve fit for $D$. tertiolecta is interpolation

Other species, clones or groups have $\mathrm{pH}$ optimum for growth rate (or substrate uptake) well above equilibrium $\mathrm{pH}$. Growing fastest at $\mathrm{pH} 8.5$ or higher are Peridinium sp. and Prorocentrum micans (Fig. 11), the Skeletonema costatum clone used by Thoresen et al. (1984; Fig. 13), Amphora coffeaeformis and Cocconeis scutellum var. parva (Fig. 14) and a mixture of Navicula spp. and Nitzschia spp. (Fig. 19). Phaeodactylum tricornutum has little change in growth rate from $\mathrm{pH} 7.5$ (or below) to pH 9.5 (Figs. $12 \& 15$ to 18 , Table 4). P. tricornutum can tolerate high $\mathrm{pH}$ and grow reasonably well above $\mathrm{pH} 10$, a trait not common

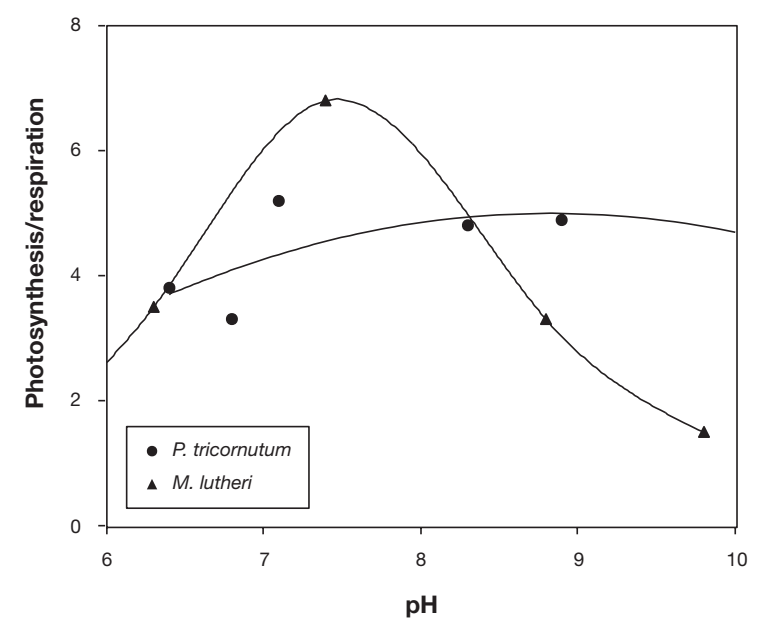

Fig. 16. Phaeodactylum tricornutum and Monochrysis lutheri. Photosynthesis/respiration ratio (Humphrey 1975). Curve fit for $P$. tricornutum is a 2nd order polynomial. Curve fit for $M$. lutheri is interpolation. Data from these experiments also appear in Table 4
Table 5. Growth of phytoplankton at $\mathrm{pH} 7.6$ to 7.8 and 8.2 from Griffis \& Chapman (1990). Growth rates are $K_{10}$ values

\begin{tabular}{|lcc|}
\hline Species & pH 7.6 to 7.8 & pH 8.2 \\
\hline Gonyaulax polyedra & Mortality & 0.061 \\
Thoracosphaera hemii & Irregular growth & 0.037 \\
Coccolithus pelagicus & 0.010 & 0.056 \\
Ditylum brightwellii & 0.167 & 0.074 \\
\hline
\end{tabular}

among the phytoplankton. The $\mathrm{pH}$ for maximum growth rate is not well constrained in a species with such little change in growth rate, but in most studies, $P$. tricornutum appears to grow fastest at $\mathrm{pH}$ higher than equilibrium.

There are 2 studies that correlated the appearance of phytoplankton species with $\mathrm{pH}$ in marine ecosystems. Yoo (1991), using a stepwise multiple correlation between dinoflagellate species abundance in Masan Bay (Korea) and environmental parameters, found that $\mathrm{pH}$ was the leading factor correlating with abundance. Diatoms did not have a similar correlation with $\mathrm{pH}$. Dinoflagellate abundance was higher with high $\mathrm{pH}$. A correlation between high $\mathrm{pH}$ and dinoflagellate abundance in marine enclosure experiments was reported by Hinga (1992). Weekly phytoplankton counts were analyzed from 17 enclosure years of a nutrient addition experiment and from 6 enclosure years of a $\mathrm{CO}_{2} \mathrm{C}$ isotope experiment. A total of 1200 observations were available with $\mathrm{pH}$ and phytoplankton counts. Among those counts were 57 occurrences when dinoflagellate populations exceeded 100 cells ml $^{-1}$. The distribution of occurrences of dinoflagellate abundance exceeding

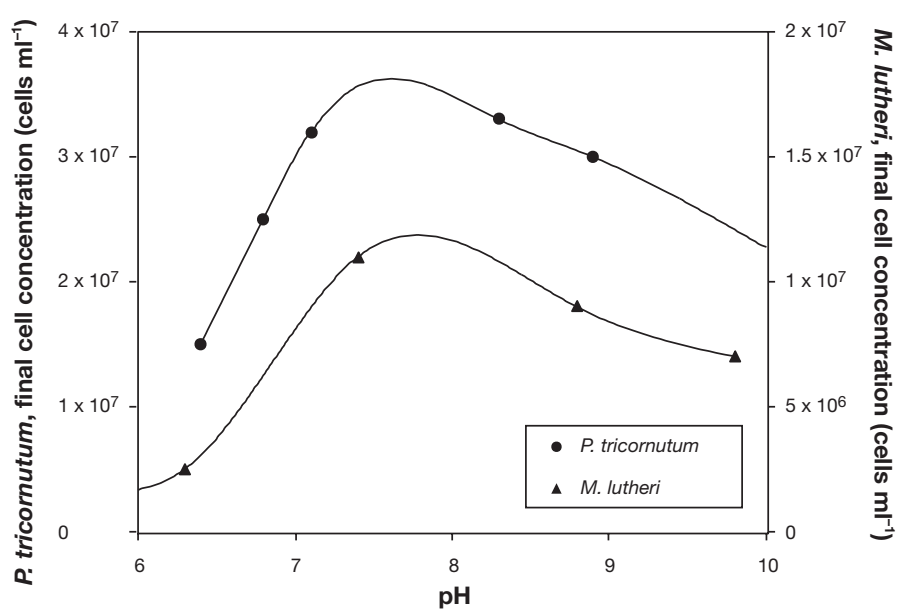

Fig. 17. Phaeodactylum tricornutum and Monochrysis lutheri. Final cell concentrations (Humphrey 1975). Data from these experiments also appear in Table 4. Curve fits are interpolations 


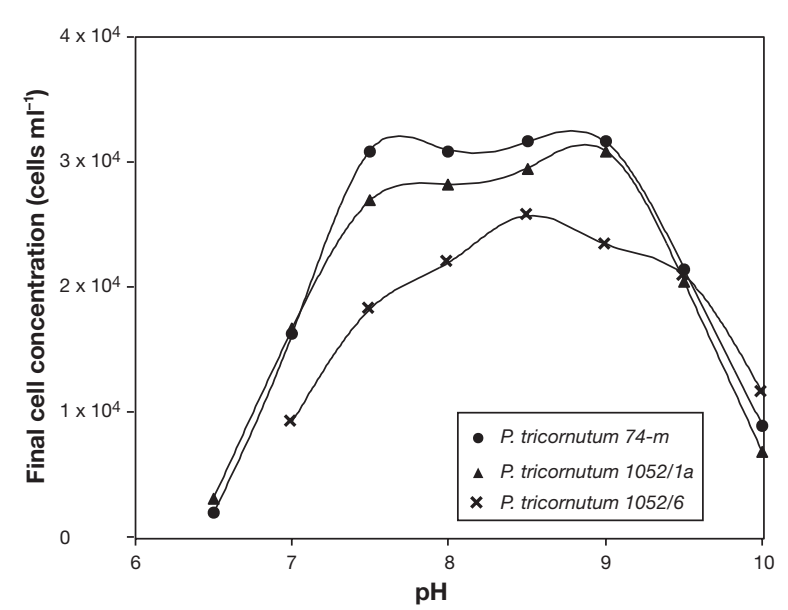

Fig. 18. Phaeodactylum tricornutum. Final cell concentrations for 3 clones (Hayward 1968). Curve fits are interpolations

100 cells $\mathrm{ml}^{-1}$ are shown in Fig. 21. The high dinoflagellate populations occurred almost exclusively during the relatively infrequent periods of high $\mathrm{pH}$. There were 6 dinoflagellate blooms with populations above 500 cells $\mathrm{ml}^{-1}$. All 6 blooms occurred at $\mathrm{pH} 8.4$ or greater. These dinoflagellate blooms developed after the $\mathrm{pH}$ was raised by a diatom bloom or an experimental procedure. Species found at high $\mathrm{pH}$ in these enclosure experiments were Peridinium spp. (by far the most common), Heterocapsa triquetra, Exuviella sp., Amphidinium sp., Gymnodinium sp., Scrippsiella sp.

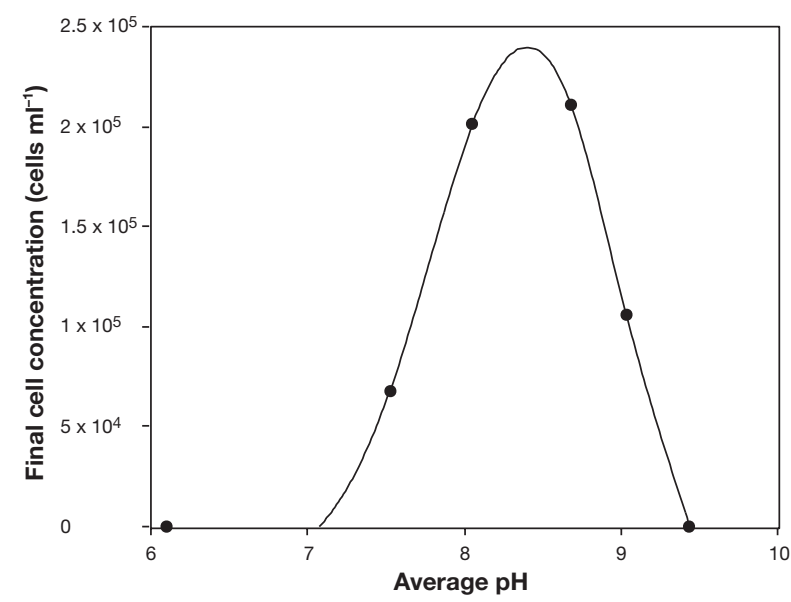

Fig. 19. Cultures dominated by Navicula spp. and Nitzschia spp. Final cell concentrations (Bachrach \& Lucciardi 1932). Only the results of their plugged experiment (cultures covered with paraffin oil) are shown here. In the plugged experiment, the $\mathrm{pH}$ of the cultures was relatively stable. Final cell concentrations are plotted against the average of initial and final $\mathrm{pH}$ for the cultures. Curve fit is interpolation

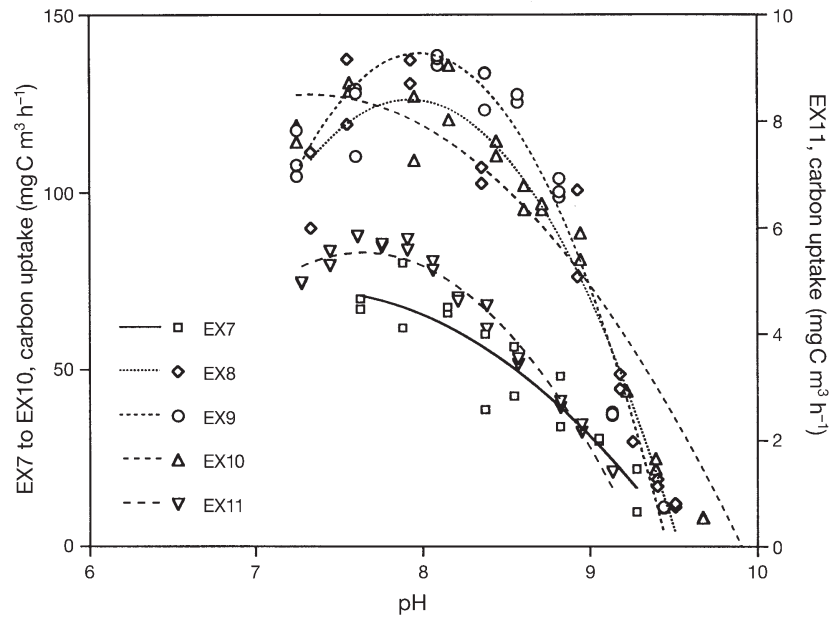

Fig. 20. C fixation measured by ${ }^{14} \mathrm{C}$ uptake in mixed populations of phytoplankton (Chen 1986, Chen \& Durbin 1994). The $\mathrm{pH}$ of the water from each enclosure before the $\mathrm{pH}$ was adjusted was EX7 $=9.05, \mathrm{EX} 8=8.93, \mathrm{EX} 9=8.82, \mathrm{EX} 10=8.94$ and EX11 $=8.21$. Curve fits are 2 nd order polynomials

and Dissodinium lenticulum. Not all dinoflagellate species had an association with high $\mathrm{pH}$. Blooms (over 100 cells ml $^{-1}$ ) of Prorocentrum redfieldi and Prorocentrum gracile were found at $\mathrm{pH} 8.0$ to 8.1. Dinophysis acuminata was found in high abundance in a single month long bloom that occurred at $\mathrm{pH}<7.5$.

The $\mathrm{pH}$ for maximum growth (maxima in final cell concentration, growth rate, or substrate uptake rate) for each study are shown in Figs. 8 to 19 and from Table 4 are compiled in Fig. 22. Where there was a range of $\mathrm{pH}$ that could represent a broad maximum,

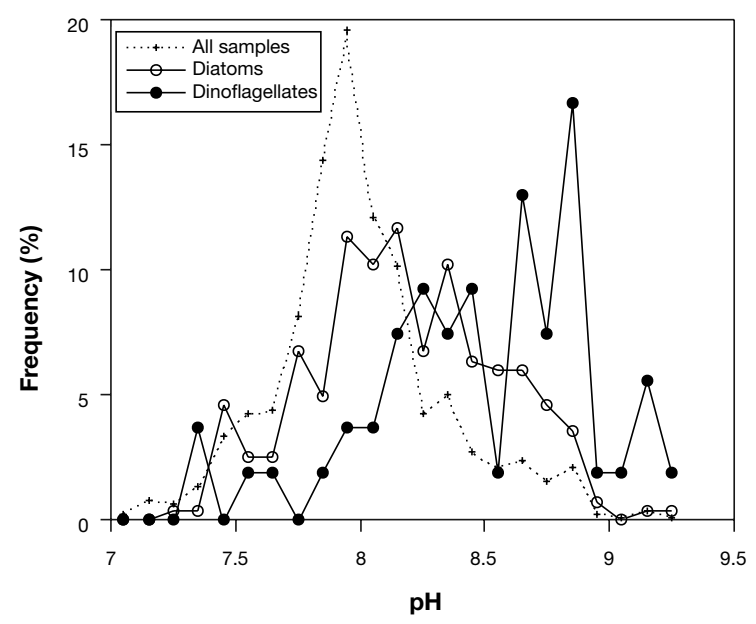

Fig. 21. Frequency of dinoflagellate and diatom abundances of over 100 cells ml ${ }^{-1}$ and frequency of all $\mathrm{pH}$ measurements where phytoplankton cells were counted in 2 marine enclosure experiments (Hinga 1992). Intervals of $0.1 \mathrm{pH}$ 
bars connect the high and low $\mathrm{pH}$ of that region. Maxima are found at $\mathrm{pH}$ as low as 6.3 and as high as 10. The species in Fig. 22 are grouped by taxonomic class. Clear preference for low or high $\mathrm{pH}$ does not appear to be a characteristic of any class. The 3 classes with several species each have species with maxima above and below equilibrium $\mathrm{pH}$. Chlorophyceae and Cryptophyceae are represented by only 1 species each.

Among the diatoms, $\mathrm{pH}$ at maximum rate ranges from 6.3 (Nitzschia closterium) to about 10. The preference for high $\mathrm{pH}$ is represented by most of the results for Phaeodactylum tricornutum and by Navicula spp. and Nitzschia spp. Five species have maxima at $\mathrm{pH}$ of 7.5 to 8 and 2 have maxima at about 8.5. Although there are only 2 data points per species (Table 5), Griffis \& Chapman (1990) found the diatom Ditylum brightwellii grew faster at $\mathrm{pH} 7.6$ to 7.8 than at $\mathrm{pH} 8.2$.

The 5 dinoflagellates have maxima at $\mathrm{pH}$ as low as 7.0 (Amphidinium carterae) and as high as 9.5 (Peri- dinium sp.). Gymnodidium splendens had a maxima at pH 7.3 to 7.6, Prorocentrum micans at pH 8.5 and Pyrodinium bahamense at pH 8.0. Gonyaulax polyedra and Thoracosphaera heimii were unable to grow, or grew poorly at pH 7.6 to 7.8 (Table 5); therefore, these 2 species may possibly be grouped with dinoflagellates that grow better at high $\mathrm{pH}$ (unless they have a very narrow range of $\mathrm{pH}$ for growth). Hwang \& Lu (2000) reported that Alexandrium minutum grew faster at pH 7.5 than at 8.5.

Three of the prymnesiophytes had maxima at $\mathrm{pH}$ below 8 . The remaining species had a maximum at 8.2. Coccolithus pelagicus grew faster at $\mathrm{pH} 8.2$ than at lower pH (Table 5).

\section{Sensitivity to $\mathrm{pH}$ range}

Only a subset of the studies can be used to examine the sensitivity to a range in $\mathrm{pH}$. Sensitivity is used here

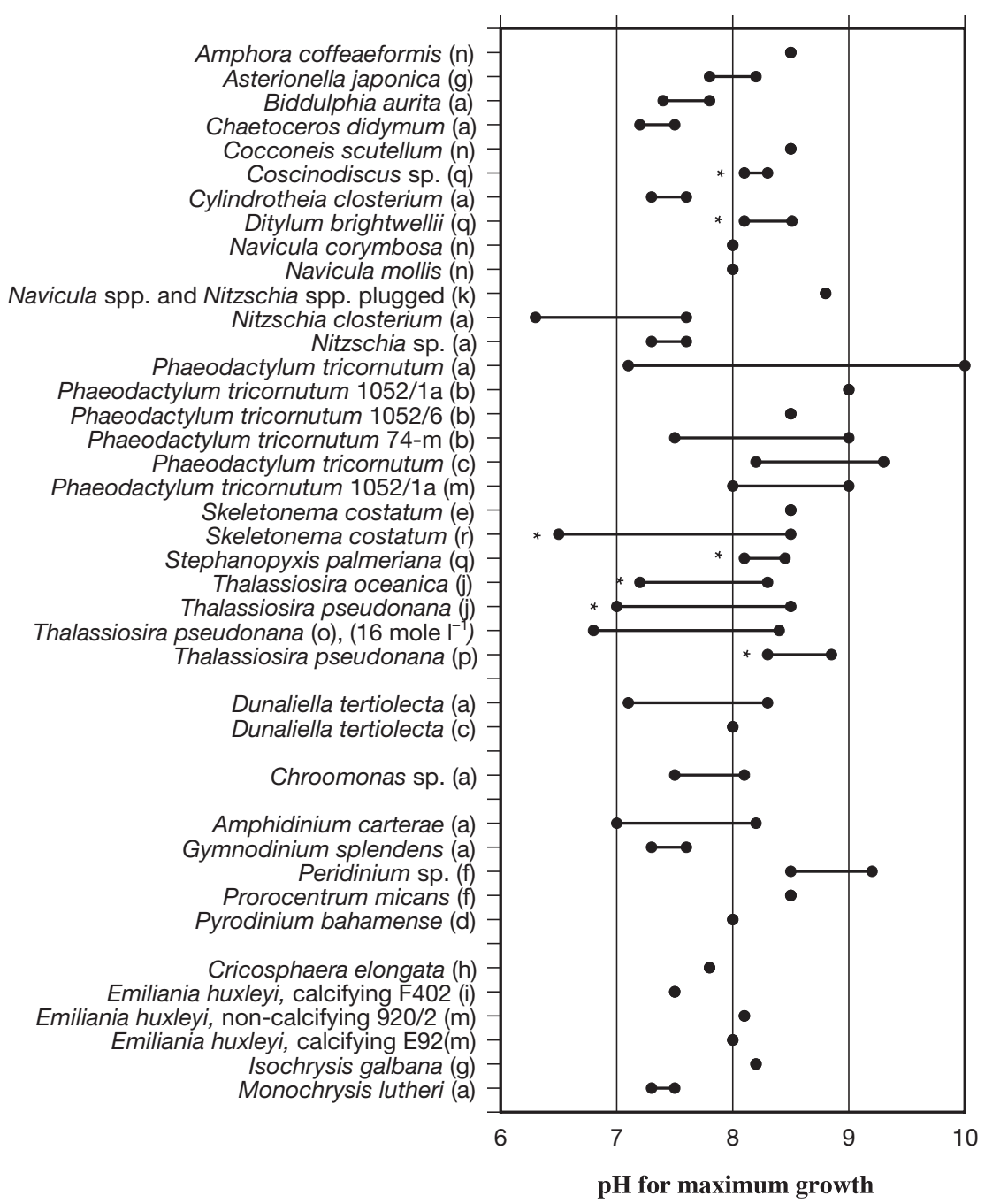

Fig. 22. Maxima in growth, growth rate, substrate uptake, production or photosynthesis/respiration ratio (P/R). Where there was no clear maximum resulting from high values at 2 widely different $\mathrm{pH}$ values, the high and low $\mathrm{pH}$ values of the broad maximum were plotted and connected. Bars marked with * indicate where the data did not extend to lower values so the range for constant growth may extend to lower values. For the studies by Humphrey (1975), the range bars represent the range of different estimates of maxima from the 3 types of measures he reported (Table 4). Sources are indicated in parentheses: (a) Humphrey (1975); (b) Hayward (1968); (c) Goldman et al. (1982a); (d) is Blackburn \& Oshima (1989); (e) Thoresen (1984); (f) Barker (1935); (g) Kahn \& Fogg (1958a,b); (h) Swift \& Taylor (1966); (i) Paasche (1966); (j) Chen \& Durbin (1994); (k) Bacharach \& Lucciardi (1932); (m) Johnston (1996): (n) Wang et al. (1998); (o) Pruder (1979); (p) Pruder \& Bolton (1979); (q) Goldman (1999); (r) Taraldsvik \& Myklestad (2000) 
to describe the magnitude of change in growth rate at $\mathrm{pH}$ higher and lower than the $\mathrm{pH}$ for maximum growth rate. The sensitivity to changes in $\mathrm{pH}$ cannot be determined from studies where only final cell density was reported. The percentage difference in final population levels for different $\mathrm{pH}$ levels, assuming exponential growth, depends upon the length of the incubation. Longer incubation periods would give a higher apparent sensitivity to $\mathrm{pH}$ variability than shorter incubation periods.

The changes in growth rate (or substrate uptake) for a given change in $\mathrm{pH}$ vary considerably. Some species are rather insensitive to changes in $\mathrm{pH}$. Most notable of these is Phaeodactylum tricornutum, which has been examined more times than any other species. $P$. tricornutum grows readily from $\mathrm{pH} 6.1$ to over 10 . The ability to tolerate and grow in extremely high $\mathrm{pH}$ is why $P$. tricornutum often dominates large scale outdoor cultures where $\mathrm{pH}$ is not regulated and may rise above 10 (Goldman et al. 1982b).

As noted above, there are a number of examples of species which have a broad plateau of nearly constant growth. These include Skeletema costatum (Taraldsvik \& Myklestad 2000; Fig. 9), Thalassiosira oceanica (Fig. 9) and T. pseudonana (Fig. 10) However, unlike the case for Phaeodactylum tricornutum, the growth rates drop off sharply at $\mathrm{pH}$ above the broad plateau of no change in growth rate. By $\mathrm{pH} 9 \mathrm{~S}$. costatum, T. oceanica and T. pseudonana grew at about half their maximum rate and by pH 9.5 grew at less than $20 \%$ of their maximum rate. Other examples of a plateau include the region of constant growth in the $\mathrm{pH}$ drift experiments (Goldman 1999) for Stephanopyxis palmeriana, Coscinodiscus sp. and Ditylum brightwellii.

The 4 species of benthic diatoms (Fig. 14) are rather insensitive to changes in $\mathrm{pH}$. At $0.5 \mathrm{pH}$ units above or below their maximum growth rate, these species grew only 4 to $7 \%$ slower than at their maximum. At $1 \mathrm{pH}$ unit above or below their maximum, their growth rate was only reduced by 12 to $37 \%$.

However, there are species relatively sensitive to changes in $\mathrm{pH}$. The most striking example is that of the 2 clones of Emiliania huxleyi (Johnston 1996). These 2 clones had strikingly and conversely different changes in growth rates from each other at high and low $\mathrm{pH}$ (Fig. 12). For example, the growth rate of the calcifying clone decreased to only $10 \%$ of its maximum growth rate with an decrease in $\mathrm{pH}$ from 8.1 to 7.6 . The noncalcifying clone dropped to $14 \%$ of its maximum growth rate with an increase of $\mathrm{pH}$ from 8.17 to 8.5.

The $\mathrm{NO}_{3}^{-}$uptake rate of Skeletonema costatum in the experiments of Thoresen et al. (1984; Fig. 13) drops off sharply at the high $\mathrm{pH}$. The uptake rate is reduced by only $15 \%$ at $\mathrm{pH} 9$ from the maximum rate found at $\mathrm{pH}$ 8.5. However, the species failed to grow at $\mathrm{pH} 9.5$.
Similarly, a Peridinium sp. (Fig. 11) grew at $85 \%$ of its maximum rate at $\mathrm{pH} 9.5$, but failed to grow at all at pH 9.8.

Fig. 23 provides a graphical summary of the growth rate sensitivities derived from Figs. 8 to 16. Most species, or clones, grow at over $80 \%$ of their maximum growth rate within $0.5 \mathrm{pH}$ unit of their optimum $\mathrm{pH}$. There are a few examples of species or clones that grow much more slowly even with this small a change in $\mathrm{pH}$. At $1.0 \mathrm{pH}$ unit above or below the $\mathrm{pH}$ optimum, most species or clones have growth rates that are 50 to $80 \%$ of their maximum growth rate.

\section{DISCUSSION}

Seawater pH may exert an influence on phytoplankton growth via a number of possible mechanisms. At high $\mathrm{pH}, \mathrm{C}$ limitation may occur especially in species that cannot utilize bicarbonate (Raven 1970, Burns \& Beardall 1987, Nimer \& Merrett 1992). Seawater pH may change the chemical speciation of elements in seawater, for example $\mathrm{Cu}$, that might have an inhibitory effect on phytoplankton (Kester 1986). Changes in $\mathrm{pH}$ of natural waters may have an indirect effect
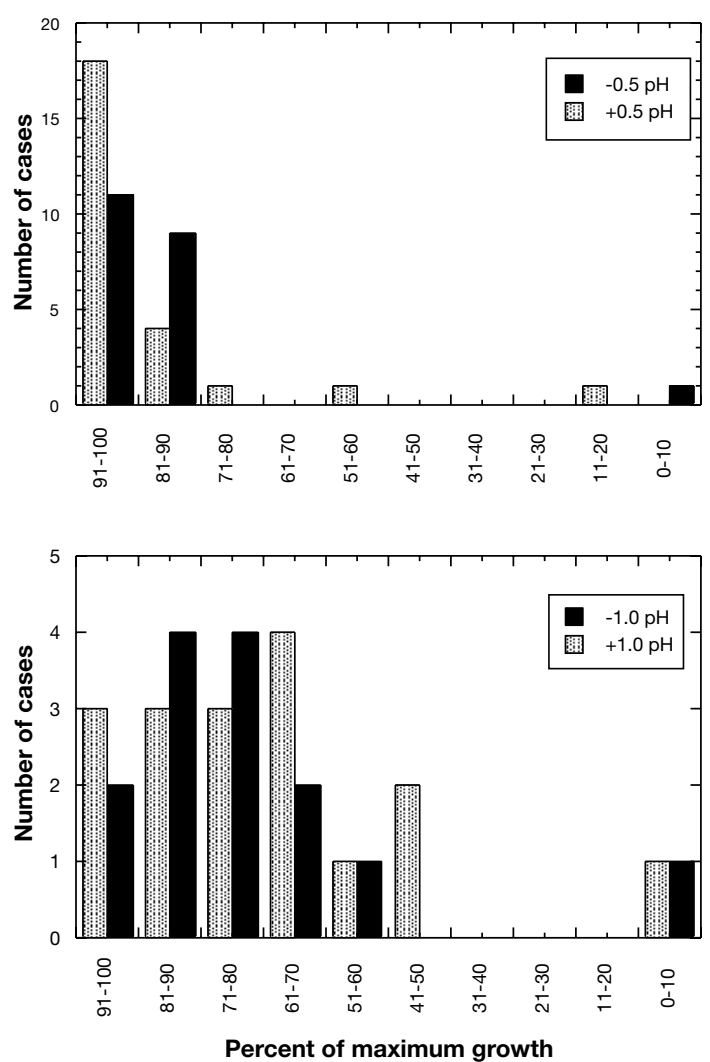

Fig. 23. Reductions in growth rate or substrate uptake rate, at $\pm 0.5 \mathrm{pH}$ (upper panel) and $\pm 1.0 \mathrm{pH}$ (lower panel) 
on phytoplankton by altering equilibria between sorbed and dissolved phases of metals, hence altering dissolved metal concentrations (Granéli \& Haraldsson 1993).

There may be an ion balance effect. At high or low $\mathrm{pH}$, cells may have to spend energy maintaining an internal pH necessary for cell function (Raven 1980, Raven \& Lucas 1985). Finally, the reaction rate of enzymes is $\mathrm{pH}$ dependent. Deviation from optimum $\mathrm{pH}$ for intracellular or surface membrane bound enzymes may impair cellular function. It seems likely that seawater $\mathrm{pH}$ may affect phytoplankton cells by multiple mechanisms simultaneously. Further, there is no reason to expect all species to have the same physiological mechanism for their exhibited $\mathrm{pH}$ effects. For example, different species have different capabilities for production of extracellular carbonic anhydrase to speed up the equilibrium between bicarbonate and free $\mathrm{CO}_{2}$ (Nimer et al. 1997), a strategy to allow growth where free $\mathrm{CO}_{2}$ may be limiting by metabolic drawdown of free $\mathrm{CO}_{2}$ concentrations near the cell.

The studies reviewed here provide only slight insight into the mechanisms of the $\mathrm{pH}$ effect. C limitation due to low concentrations of free $\mathrm{CO}_{2}$ may well be the mechanism for reduced growth rate at high $\mathrm{pH}$ for some of the species. However, this mechanism seems very unlikely to account for the reduction in growth rate where observed at low $\mathrm{pH}$. For the studies where cultures were grown at a fixed free $\mathrm{CO}_{2}$ concentration across a pH range, the observed $\mathrm{pH}$ effects are not due to a limitation of free $\mathrm{CO}_{2}$ concentrations. Those experiments include results for the species Cricosphaera elongata (Fig. 8), Thalassiosira pseudonana (Fig. 10, Pruder 1979), Emiliania huxleyi (Fig. 12) and Phaeodactylum tricornutum (Figs. 12 \& 18).

Goldman (1999) drew a similar conclusion in laboratory experiments with Stephanopyxis palmeriana, Coscinodiscus sp. and Ditylum brightwellii. Cultures of these diatoms were allowed to grow and draw down the $\mathrm{CO}_{2}$ and raise the $\mathrm{pH}$. Once the $\mathrm{pH}$ of cultures rose above pH 8.45 for $S$. palmeriana, 8.51 for D. brightwelli and 8.31 for Coscinodiscus sp., the growth rate for each species decreased from the constant growth rate at lower $\mathrm{pH}$. As the growth rate of these species was not affected by turbulent mixing, Goldman (1999) concluded that free $\mathrm{CO}_{2}$ limitation was not the cause for the decreased growth rate.

Even though the physiological mechanisms of $\mathrm{pH}$ effects on phytoplankton growth may not be well understood, it is still possible to infer the possible ecological consequences of the observed $\mathrm{pH}$ effects. Humphrey (1975) in his study of $\mathrm{pH}$ effects determined the $\mathrm{pH}$ range that will support growth for individual species (Table 4). Some of these species have limits for growth that fall within the range of $\mathrm{pH}$ found occasion- ally in coastal environments. For example, Biddulphia aurita did not grow above $\mathrm{pH} 8.7$ and Cylindrotheca closterium did not grow above $\mathrm{pH}$ 8.5. Amphidinium Carterae, Chaetoceros didymum, Chroomonas sp. and Gymnodinium splendens did not grow below pH 7.0. A $\mathrm{pH}$ near the extreme values found in coastal environments, $\mathrm{pH}$ over 9 or below 7, will exclude certain species from growing and hence occurring in the community except as a residual from earlier growth.

The ability of extreme pH-tolerant species to dominate in high $\mathrm{pH}$ conditions was observed in direct competition experiments. Goldman (1982b) conducted competition experiments in continuous culture between Phaeodactylum tricornutum and Dunaliella tertiolecta. As would have been predicted from the relationship between $\mathrm{pH}$ and algal biomass for each individual species (Fig. 15), the relative dominance in 2 species continuous cultures was influenced by $\mathrm{pH}$. At higher $\mathrm{pH}, P$. tricornutum, which is known to grow well at high $\mathrm{pH}$, dominated over $D$. tertiolecta, which has maximum growth near $\mathrm{pH}$ 8.0.

There are 4 species for which there are more than 1 study. In 2 cases, the studies give a similar picture of the $\mathrm{pH}$ response of the species. All the studies of Phaeodactylum tricornutum indicate a very wide $\mathrm{pH}$ range for growth and a tolerance of very high $\mathrm{pH}$ (Figs. 12 \& 15 to 18, Table 4). The 2 studies of Thalassiosira pseudonana show a similar response in each case (Fig. 10) with a broad region of $\mathrm{pH}$ from about 7 to 8.2 or 8.5 with little change in growth rate. At higher $\mathrm{pH}$ the growth rate in both studies drops off sharply. The 3 clones of Emiliania huxleyi show strikingly different behavior (Figs. $12 \& 13$ ). As 2 of the clones were grown under identical experimental conditions, the differences between them at least are not an experimental artifact. If it is found that species commonly have strains with very different response to $\mathrm{pH}$ change, a pH effect on the timing and abundance of a species may not be exhibited at the species level. Different strains could grow under different $\mathrm{pH}$ conditions. Nevertheless, a pH effect would still be important in determining the timing and abundance of different clones of the same species.

In the 2 studies with Skeletonema costatum (Figs. 9 \& 13) the growth rate study indicates a broad plateau in growth rate (Fig. 9), while $\mathrm{NO}_{3}{ }^{-}$uptake rate study indicates a preference for high $\mathrm{pH}$ (Fig. 13). Given that the amino acid composition of $S$. costatum cells was $\mathrm{pH}$ dependent (Taraldsvik \& Myklestad 2000), it seems possible that the $\mathrm{NO}_{3}{ }^{-}$uptake rate at variable $\mathrm{pH}$ is not directly correlated to growth rate. Hence, the different patterns exhibited by the $2 S$. costatum studies may indicate real differences between clones, or may simply be a result of the use of non-equivalent measures of growth rate. 
The results of the $\mathrm{C}$ uptake experiment by Chen (1986) and Chen \& Durbin (1994) indicate that pH affects rates of primary production (Fig. 20). Carbon fixation rate for each of the 5 mixed phytoplankton communities was highest near $\mathrm{pH} 8$ and decreased with increasing $\mathrm{pH}$. At $\mathrm{pH} 9$ the carbon fixation rates were about $50 \%$ of the maximum rates. The $\mathrm{pH}$ values used in these experiments do not extend to very low $\mathrm{pH}$, but for 3 of the 5 communities there are also indications of a decrease in primary production rate toward low $\mathrm{pH}$. At the time of sampling the communities for the carbon uptake experiments, the $\mathrm{pH}$ of the water in the enclosures used for Expts 7, 8, 9 and 10 was between 8.8 and 9.1. The composition of the community had not developed with species that were better able to fix carbon at high $\mathrm{pH}$. Hence, blooms may be self limiting when sufficient $\mathrm{CO}_{2}$ is taken up to drive the system to high $\mathrm{pH}$. The effects of $\mathrm{pH}$ are not limited to the more extreme levels of $\mathrm{pH}$. As already discussed, many species have maximum growth at $\mathrm{pH}$ above or below equilibrium pH. Accordingly, their growth rates change significantly with $\mathrm{pH}$ changes near equilibrium $\mathrm{pH}$ (e.g. Figs. 11 \& 13).

The effects of changes in growth rate near equilibrium $\mathrm{pH}$ can be illustrated by modeling a simple growth experiment. Fig. 24 shows how the final population abundance is affected by $\mathrm{pH}$ for a 2 species calculation where 1 species has maximum growth at low $\mathrm{pH}$ and the other at high $\mathrm{pH}$. The growth rates for Asterionella japonica (Fig. 8) were used to represent a species with maximum growth rate at low $\mathrm{pH}$ (7.8). The growth rates for the Peridinium sp. (Fig. 11) were used to represent a species with maximum growth at high pH. Final populations after $7 \mathrm{~d}$ exponential growth from equal initial abundance for each species were calculated. At low pH, 7.6 to 7.8 , the Peridinium sp. would only make up 7 to $12 \%$ of the final total abundance. At $\mathrm{pH} 8$, Peridinium sp. constitutes $22 \%$ of the final total abundance. At $\mathrm{pH}$ of 8.3 , Peridinium sp. makes up $50 \%$ of the total abundance and at $\mathrm{pH} 8.5$ constitutes $78 \%$ of the total abundance. The example is not expected to predict real situations as the growth rates of phytoplankton are influenced by many factors in addition to $\mathrm{pH}$. However, it does illustrate that changes in $\mathrm{pH}$, which are not far from equilibrium $\mathrm{pH}$, may influence the relative abundance of species in mixed populations.

There is, at present, no direct evidence to link $\mathrm{pH}$ and the occurrence of nuisance phytoplankton species. Indeed, one nuisance species, Pyrodinium bahamense has nothing in its response to $\mathrm{pH}$ (Fig. 11) to suggest that extreme $\mathrm{pH}$ conditions would lead to blooms. Nevertheless, it is tempting to hypothesize that $\mathrm{pH}$ contributes to the apparent worldwide increase in outbreaks of nuisance blooms (e.g. Hallegraeff 1993).

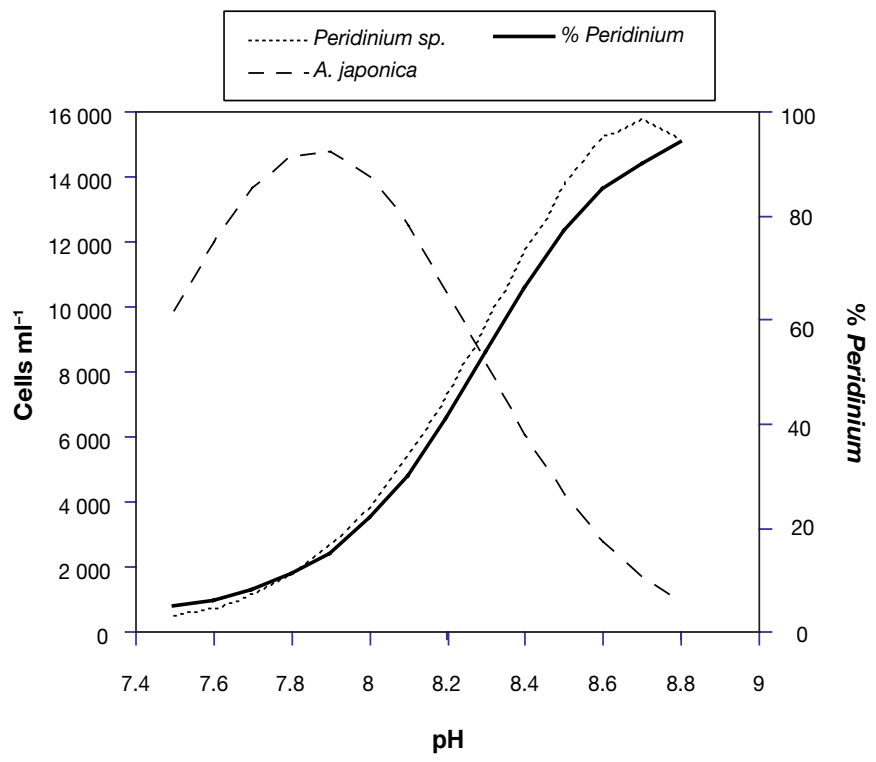

Fig. 24. Peridinium sp. and Asterionella japonica. Final population levels after $7 \mathrm{~d}$ exponential growth from initial population levels of 10 cells $\mathrm{ml}^{-1}$. Growth rates at each $\mathrm{pH}$ were calculated from 2nd order polynomial curve fits to the data in Figs. $7 \& 11$. The percent Peridinium is the percent of the combined populations of the 2 species

Extreme pH values (i.e. 7 or 9) occur infrequently, as do many nuisance blooms. With the eutrophication of coastal ecosystems, the $\mathrm{pH}$ of coastal environments may be driven to more frequent or greater extremes (e.g. Fig. 6), giving greater opportunity for species with tolerance to extreme $\mathrm{pH}$ to bloom. The $\mathrm{pH}$ variability in an environment subject to both nutrient enrichment and organic $\mathrm{C}$ enrichment depends upon many hydrographic and ecological factors, as discussed above. Hence, each estuary will have a unique response. There may be no general pattern of $\mathrm{pH}$ variability shared among estuaries, other than an increased frequency of extreme values with timing that is difficult to predict. This, in turn, may lead to increased frequency of previously rare occurrences of certain species.

\section{SUMMARY AND CONCLUSIONS}

The $\mathrm{pH}$ of seawater in many coastal environments routinely varies by $1 \mathrm{pH}$ unit from about $\mathrm{pH} 7.5$ to 8.5. There are occasional occurrences of $\mathrm{pH}$ greater than 9 or less than 7 . $\mathrm{pH}$ values outside the range of 7.0 to 8.5 can preclude the growth of some species. At extreme $\mathrm{pH}$, only species with a tolerance for high or low $\mathrm{pH}$ would grow and dominate the community. Some species have maximum growth near equilibrium $\mathrm{pH}$ and others have a range of $\mathrm{pH}$, encompassing equilibrium $\mathrm{pH}$, where growth rate is not affected by changes in 
$\mathrm{pH}$. The growth rate of these species will be largely unaffected by small changes near equilibrium $\mathrm{pH}$. Other species have maximum growth at $\mathrm{pH}$ above or below equilibrium $\mathrm{pH}$ (Fig. 22). The growth rate of these species changes at $\mathrm{pH}$ near equilibrium $\mathrm{pH}$. Hence, for these species, their growth rate and abundance in a mixed community could be influenced by $\mathrm{pH}$ variability even near equilibrium.

If a coastal ecosystem has a regular $\mathrm{pH}$ cycle, $\mathrm{pH}$ may play a role in a seasonal succession of phytoplankton species. Seawater $\mathrm{pH}$ may limit the rate of primary production, growth, and total abundance of phytoplankton in blooms. Phytoplankton communities were able to fix $\mathrm{C}$ only half as fast at about $\mathrm{pH} 9$ compared to $\mathrm{pH}$ 8. This reduction may allow sinking and grazing to reduce the size of the population from that which would have been obtained without a $\mathrm{pH}$ effect on $\mathrm{C}$ fixation.

$\mathrm{pH}$ effects should be considered when culturing phytoplankton or conducting laboratory studies of phytoplankton growth rates as a function of nutrients, trace elements or light etc. Laboratory cultures are often grown at relatively high cell densities; hence, there is greater likelihood that the cultures may take up enough $\mathrm{CO}_{2}$ to significantly alter the $\mathrm{pH}$ of the system. If conditions in the experiments are not controlled for $\mathrm{pH}$, effects attributed to other factors may in reality be a $\mathrm{pH}$ effect.

Finally, the existing data suggest that it is inappropriate to a priori exclude $\mathrm{pH}$ as a factor in coastal marine phytoplankton ecology. It seems probable that upon further study, $\mathrm{pH}$ will prove to be a non-trivial factor in phytoplankton dynamics in coastal environments.

Acknowledgements. This work was supported in part by grant no. NA89AA-D-SG082 from the NOAA Coastal Ocean Program. I wish to thank M. E. Q. Pilson for his helpful discussions and comments on portions of the manuscript. I thank S. Pavignano for her work in preparation of the data and $\mathrm{H}$. Jeon for her efforts in the literature search. I thank J. Rines for her tutoring on phytoplankton taxonomy and N. Lewis for editorial assistance, and the manuscript reviewers for their many helpful suggestions and comments.

\section{LITERATURE CITED}

Bachrach E, Lucciardi N (1932) Influence de la concentration en ions hydrogène $(\mathrm{pH})$ sur la multiplication de quelques diatomèes marines. Rev Algol 6:251-261

Barker HA (1935) The culture and physiology of the marine dinoflagellates. Arch Mikrobiol 6:157-181

Blackburn SI, Oshima Y (1989) Review of culture methods for Pyrodinium bahamense. In: Hallegraeff GM, Maclean JL (eds) Biology, epidermiology and management of Pyrodinium red tides. Fisheries Department, Ministry of Development, Manila, p 257-266
Brussaard CPD, Gast GJ, van Duyl FC, Riegman R (1996) Impact of phytoplankton bloom magnitude on a pelagic microbial food web. Mar Ecol Prog Ser 144:211-221

Burns BD, Beardall J (1987) Utilization of inorganic carbon by marine microalgae. J Exp Mar Biol Ecol 107:75-86

Chen CY (1986) Effect of pH on the growth and carbon uptake of marine phytoplankton. MSc thesis, University of Rhode Island

Chen CY, Durbin EG (1994) Effects of pH on the growth and carbon uptake of marine phytoplankton. Mar Ecol Prog Ser 109:83-94

Culberson CH, Church TM (1988) Data from the CDR Cruises. DEL-SG-05-90, University of Delaware, Newark

Culberson CH, Sharp JH, Church TM, Lee BW (1982) Data from the SALSX Cruises. DEL-SG-05-82, University of Delaware, Newark

Culberson $\mathrm{CH}$, Church TM, Franke AC, Sharp JH and 6 others (1987a) Data from the SALT Cruises. DEL-SG-10-87, University of Delaware, Newark

Culberson CH, Pennock JR, Lee BW, Biggs RB, Church TM, Sharp JH (1987b) Yabled Cruised Part II, Data from YABLED-17 through YABLED-26, January-October 1985. DEL-SG-17-87, University of Delaware, Newark

Culberson CH, Pennock JR, Lee BW, Biggs RB, Church TM, Sharp JH (1987c) Data From the YABLED Cruises. DELSG-11-87, University of Delaware, Newark

Dixit SS, Smol JP, Kingston JC, Charles DF (1992) Diatoms: Powerful indicators of environmental change. Environ Sci Technol 26:23-33

Eadie BJ, McKee BA, Lansing MB, Robbins JA, Metz S, Trefry JH (1994) Records of nutrient-enhanced coastal ocean productivity in sediments from the Louisiana continental shelf. Estuaries 17:754-765

Frithsen JB, Lane PA, Keller AA, Pilson MEQ (1985) Effects of inorganic nutrient additions in coastal areas: A mesocosm experiment data report, Vol 2. University of Rhode Island, Kingston

Gerlach SA (1990) Nitrogen, phosphorus, plankton and oxygen deficiency in the German Bight and in the Kiel Bay. Kiel Meeresforsch Sonderh 7:1-341

Goldman JC (1999) Inorganic carbon availability and the growth of large marine diatoms. Mar Ecol Prog Ser 180:81-91

Goldman JC, Azov Y, Riley CB, Dennett MD (1982a) The effect of $\mathrm{pH}$ in intensive microalgal cultures. I. Biomass regulation. J Exp Mar Biol Ecol 57:1-13

Goldman JC, Riley CB, Dennett MR (1982b) The effect of pH in intensive microalgal cultures. II. Species competition. J Exp Mar Biol Ecol 57:15-24

Granéli E, Haraldsson C (1993) Can increased leaching of trace metals from acidified areas influence phytoplankton growth in coastal waters? Ambio 22:308-311

Griffis K, Chapman DJ (1990) Modeling cretaceous - tertiary boundary events with extant photosynthetic plankton: effects of impact-related acid rain. Lethaia 23:379-383

Hallegraeff GM (1993) A review of harmful algal blooms and their apparent global increase. Phycologia 32:79-99

Harding LW Jr (1994) Long-term trends in the distribution of phytoplankton in Chesapeake Bay: roles of light, nutrients and streamflow. Mar Ecol Prog Ser 104:267-291

Hayward J (1968) Studies on the growth of Phaeodactylum tricornutum. J Mar Biol Assoc UK 48:657-666

Hinga KR (1990) Alteration of phosphorus dynamics during experimental eutrophication of enclosed marine ecosystems. Mar Pollut Bull 21:275-280

Hinga KR (1992) Co-occurrence of dinoflagellate blooms and high $\mathrm{pH}$ in marine enclosures. Mar Ecol Prog Ser 86: 181-187 
Hires RI, Stroup ED, Seitz RC (1963) Atlas of the distribution of dissolved oxygen and $\mathrm{pH}$ in Chesapeake Bay, 1949-1961. Ref\#63-4, Chesapeake Bay Institute, Johns Hopkins University

Hodgkiss IJ, Chan BSS (1987) Phytoplankton dynamics in Tolo Harbour. Asian Mar Biol 4:103-112

Humphrey GF (1975) The photosynthesis:respiration ratio of some unicellular marine algae. J Exp Mar Biol Ecol 18: 111-119

Hwang DF, Lu YH (2000) Influence of environmental and nutritional factors on growth, toxicity, and toxin profile of dinoflagellate Alexandrium minitum. Toxicon 38: 1491-1503

Johnston AM (1996) The effect of environmental variables on ${ }^{13} \mathrm{C}$ discrimination by two marine phytoplankton. Mar Ecol Prog Ser 132:257-263

Kain JM, Fogg GE (1958a) Studies on the growth of marine phytoplankton I. Asterionella Japonica Gran. J Mar Biol Assoc UK 37:397-413

Kain JM, Fogg GE (1958b) Studies on the growth of marine phytoplankton II. Isochrysis galbana Parke. J Mar Biol Assoc UK 37:781-788

Keller AA (1988a) An empirical model of primary productivity (14-C) using mesocosm data along a nutrient gradient. J Plankton Res 10:813-834

Keller AA (1988b) Estimating phytoplankton productivity from light availability and biomass in the MERL mesocosms and Narragansett Bay. Mar Ecol Prog Ser 45:159-168

Keller AA (1989) Modeling the effects of temperature, light, and nutrients on primary productivity: an empirical and a mechanistic approach compared. Limnol Oceanogr 34: 82-95

Keller AA, Rice RL (1989) Effects of nutrient enrichment on natural populations of the brown tide phytoplankton Aureococcus anophagefferens (Chrysophyceae). J Phycol 25:636-646

Kelly JR, Berounsky VM, Nixon SW, Oviatt CA (1985) Benthic-pelagic coupling and nutrient cycling across an experimental eutrophication gradient. Mar Ecol Prog Ser 26:207-219

Kester DR (1986) Equilibrium models in seawater: applications and limitations. In: Bernhard $\mathrm{M}$, Brinckman FE, Sadler PJ (eds) The importance of chemical 'speciation' in environmental processes. Springer Verlag, Berlin, p 337-363

Laughinghouse BR, Kuenzler EJ (1971) Insolation, pH, and turbidity. In: Kuenzler EJ, Chestnut AF (eds) Structure and functioning of estuarine ecosystems exposed to treated sewage wastes II. Supplement to annual report for 1970-1971 to NOAA Office of Sea Grant Programs. Institute of Marine Sciences, University of North Carolina, Chapel Hill and Morehead City, North Carolina

Lebo ME, Cifuentes LA, Fogel ML, Hoch MP and 7 others (1990) Data from the Delaware Estuary SCENIC Cruises. DEL-SG-06-90, University of Delaware, Newark

McAllister CD, Parsons TR, Stephens K, Strickland JDH (1961) Measurements of primary production in coastal sea water using a large-volume plastic sphere. Limnol Oceanogr 6: 237-258

Meybeck M (1982) Carbon, nitrogen and phosphorus transport by world rivers. Am J Sci 282:401-450

Nehring D, Schulz S, Kaiser W (1984) Long-term phosphate and nitrate trends in the Baltic Proper and some biological consequences: a contribution to the discussion concerning the eutrophication of these waters. Rap P-V Reun Cons Int Explor Mer 183:193-203

Nimer NA, Merrett MJ (1992) Calcification and utilization of inorganic carbon by the coccolithophorid Emiliania huxleyi Lohman. New Phytol 121:173-177

Nimer NA, Iglesias-Rodriguez MD, Merrett MJ (1997) Bicarbonate utilization by marine phytoplankton species. J Phycol 33:625-631

Nixon SW, Pilson MEQ, Oviatt CA, Donaghay P and 4 others (1984) Eutrophication of a coastal marine ecosystem - an experimental study using the MERL microcosms. In: Fasham MJR (ed) Flows of energy and materials in marine ecosystems. Plenum Press, New York, p 105-135

Oviatt CA, Keller AA, Sampou PA, Beatty LL (1986a) Patterns of productivity during eutrophication: a mesocosm experiment. Mar Ecol Prog Ser 28:69-80

Oviatt CA, Rudnick DT, Keller AA, Sampou PA, Almquist GT (1986b) A comparison of system $\left(\mathrm{O}_{2}\right.$ and $\left.\mathrm{CO}_{2}\right)$ and $\mathrm{C}-14$ measurements of metabolism in estuarine mesocosms. Mar Ecol Prog Ser 28:57-67

Oviatt CA, Lane P, French F III, Donaghay P (1989) Phytoplankton species and abundance in response to eutrophication in coastal marine mesocosms. J Plankton Res 11: 1223-1244

Paasche E (1964) A tracer study of the inorganic carbon uptake during coccolith formation and phytosynthesis in the coccolithophorid Coccolithus huxleyi. Physiol Plant Suppl III:1-82

Pegler K, Kempe S (1988) The carbonate system of the North Sea: determination of alkalinity and $\mathrm{TCO}_{2}$ and calculation of $\mathrm{PCO}_{2}$ and Sical (Spring 1986). Mitt Geol-Paläont Inst 65: 35-87

Pilson MEQ (1998) An introduction to the chemistry of the sea. Prentice-Hall, New York

Plath DC, Johnson KS, Pytkowicz RM (1980) The solubility of calcite-probably containing magnesium-in seawater. Mar Chem 10:9-29

Price KS, Flemer DA, Taft JL, Mackiernan GB and 4 others (1985) Nutrient enrichment of Chesapeake Bay and its impact on the habitat of striped bass: a speculative hypothesis. Trans Am Fish Soc 114:97-106

Pruder GD (1979) Effect of $\mathrm{pH}$, carbon dioxide, oxygen and light on the growth of Thalassiosira Pseudonana (Hustedt) Hassle and Heimdal Clone $3 \mathrm{H}$, an important food for bivalve molluscan mariculture. DEL-SG-3-79, University of Delaware, Newark, NJ

Pruder GD, Bolton ET (1979) The role of $\mathrm{CO}_{2}$ enrichment of aerating gas in the growth of an estuarine diatom. Aquaculture 17:1-15

Raven JA (1970) Exogenous inorganic carbon sources in plant photosynthesis. Biol Rev 45:167-221

Raven JA (1980) Nutrient transport in microalgae. Adv Microbial Physiol 21:47-226

Raven JA, Lucas WJ (1985) Energy costs of carbon acquisition. In: Lucas WJ, Berry JA (eds) Inorganic carbon uptake by aquatic phytosynthetic organisms. American Society of Plant Physiologists, Rockville, MD, p 305-324

Rosenberg R, Elmgren R, Fleischer S, Jonsson P, Persson G, Dahlin H (1990) Marine eutrophication case studies in Sweden. Ambio 19:102-108

Rudnick DT, Oviatt CA (1986) Seasonal lags between organic carbon deposition and mineralization in marine sediments. J Mar Res 44:815-837

Sharp JH, Church TM, Culberson CH (1980) Data from the 1977 TransX Cruises. CMS-4-80, University of Delaware, Newark, NJ

Skirrow G (1975) The dissolved gases - carbon dioxide. In: Riley JP, Skirrow G (eds) Chemical oceanography. Academic Press, New York

Stumm W, Morgan JJ (1996) Aquatic chemistry: chemical 
equilibria and rates in natural waters. Wiley-Liss Inc, New York

Swift E, Taylor W (1966) The effect of $\mathrm{pH}$ on the division rate of the coccolithophorid Cricosphaera elongata. J Phycol 2: 121-125

Taraldsvik M, Myklestad SM (2000) The effect of pH on growth rate, biochemical composition and extracellular carbohydrate production of the marine diatom Skeletonema costatum. Eur J Phycol 35:189-194

ter Braak CJF, van Dam H (1989) Inferring pH from diatoms: a comparison of old and new calibration methods. Hydrobiologica 178:209-223

Thoresen SS, Clayton JR Jr, Ahmed SI (1984) The effect of short-term fluctuations in $\mathrm{pH}$ on $\mathrm{NO}_{3}{ }^{-}$uptake and intra-

Editorial responsibility: Otto Kinne (Editor),

Oldendorf/Luhe, Germany cellular constituents in Skeletonema costatum (Grev.) Cleve. J Exp Mar Biol Ecol 83:149-157

Wang Q, Mei L, Wang S, Ding M, Li Y, Cheng A (1998) Studies on culture conditions of benthic diatoms for feeding abalone. II. Effects of salinity, $\mathrm{pH}$, and phosphate nutrients on growth rate. Chin J Oceanol Limnol 16:78-83

Weiss RF (1974) Carbon dioxide in seawater: The solubility of a non-ideal gas. Mar Chem 2:203-215

Winker CD, Jaffe LC, Howard JD (1985) Georgia Estuarine Data 1961-1977, Vol 1. Tech Rep 85-7, Skidaway Institute of Oceanography, Savannah, GA

Yoo KI (1991) Population dynamics of dinoflagellate community in Masan Bay with a note on the impact of environmental parameters. Mar Pollut Bull 23:185-188

Submitted: March 27, 2001; Accepted: February 28, 2002

Proofs received from author(s): July 12, 2002 